\title{
Numerical Taxonomy of Haemophilus
}

\author{
By ANNETTE K. BROOM AND P. H. A. SNEATH* \\ Department of Microbiology, University of Leicester, Leicester LE1 7RH, U.K.
}

(Received 26 January 1981)

\begin{abstract}
A numerical taxonomic study of strains of Haemophilus, together with representatives of Pasteurella and Actinobacillus, showed 12 reasonably distinct phenons. These phenons corresponded in the main with recognized species. Phenon 1 contained $H$. influenzae and $H$. aegyptius, and phenon 2 represented $H$. parasuis. Phenon 3 comprised haemolytic V-requiring strains similar to $H$. parahaemolyticus. Phenons 4 and 5 were very similar, and comprised a number of V-requiring strains including $H$. parainfluenzae and $H$. paraphrophilus. Phenon 6 contained $H$. avium and a few other strains from fowls or swine. Phenon 8 represented $H$. paragallinarum and $H$. somnus, and phenon 9 contained $H$. aphrophilus strains. Phenons 7 , 10 and 11 contained strains of Pasteurella and Actinobacillus, and strains of $H$. piscium were recovered in phenon 12. The last appeared not to belong to the genus Haemophilus. A small proportion of strains were unclustered. Although the groupings were broadly satisfactory, they were not as sharply demarcated as phenons in comparable taxonomic studies, and the reasons for this are discussed.
\end{abstract}

\section{INTRODUCTION}

The genus Haemophilus was established by Winslow et al. (1917) for the influenza bacillus Haemophilus influenzae (which was designated as type species) and several other bacteria. These small, Gram-negative rods were all obligate animal parasites, aerobic and rather fastidious in their growth requirements. For growth, $H$. influenzae requires $\mathrm{X}$ factor or haematin (Fildes, 1921) and V factor or NAD (Thjotta \& Avery, 1921), and the requirement for one or both of these growth factors has been a traditional criterion for inclusion in the genus. The species were separated on growth factor requirements and the animal, host or organ attacked, but recent work (Nicolet, 1968; Sneath \& Johnson, 1973) throws doubt on whether species can be based on these attributes. A fuller review is given by Power (1978).

The genus Haemophilus lies close to Actinobacillus and Pasteurella, and the three genera may grade towards the Enterobacteriaceae. The genus is not closely associated with the Brucella-Neisseria-Moraxella area (Johnson, 1972, Johnson \& Sneath, 1973). A pilot study by Sneath \& Johnson (1973) showed three major groups corresponding to the species $H$. influenzae, $H$. parainfluenzae and $H$. aphrophilus. In a more comprehensive study, Kilian $(1976 a)$ recovered several species including $H$. influenzae, $H$. parainfluenzae, $H$. haemolyticus, $H$. haemoglobinophilus, $H$. aphrophilus, $H$. paraphrophilus, $H$. segnis, $H$. parasuis, $H$. pleuropneumoniae and $H$. paragallinarum.

The majority of the named species are listed in Table 1, together with their growth factor requirements and their usual habitats. Since this work was completed, the Approved Lists of Bacterial Names have appeared (Skerman et al., 1980), which contain the only scientific names of bacterial taxa that retain their legitimacy, together with the type strains for cultivable species. Although the Approved Lists now determine the nomenclature of bacteria, the earlier names and citations, and the earlier proposals for type and neotype strains, have been retained 
Table 1. Some named species of Haemophilus

\section{Name and citation}

H. influenzae (Lehmann \& Neumann 1896) Winslow et al. 1917

H. aegyptius (Trevisan 1889) Pittman \& Davis 1950

H. haemoglobinophilus (Lehmann \&

Neumann 1907) Murray 1939

H. parainfluenzae Rivers 1922

H. haemolyticus Bergey et al. 1923

H. parahaemolyticus Pittman 1953

H. gallinarum* Delaplane et al. 1934

H. suis* Hauduroy et al. 1937

H. paragallinarum Biberstein \& White 1969

H. parasuis Biberstein \& White 1969

H. pleuropneumoniae Shope 1964

H. influenzae-murium* (Kairies \& Schwartzer

1936) Lwoff 1939

H. aphrophilus Khairat 1940

H. paraphrophilus Zinnemann et al. 1968

$H$. paraphrohaemolyticus Zinnemann et al. 1971

H. piscium Snieszko et al. 1950

H. somnus*† Bailie 1969

H. avium Hinz \& Kunjara 1977

H. segnis Kilian 1977

H. ducreyi (Neveu-Lemaire 1921) Bergey et al. 1923

H. vaginalis Gardner \& Dukes 1955
Growth factors required

$\mathrm{X}, \mathrm{V}$

$\mathrm{X}, \mathrm{V}$

$\mathrm{X}$

$\mathrm{V}$

$\mathrm{X}, \mathrm{V}$

$\mathrm{V}$

X, V

X, V

$\mathrm{V}$

V

V

X

$\mathrm{X}, 5 \% \mathrm{CO}_{2}$

$\mathrm{V}, 5 \% \mathrm{CO}_{2}$

$\mathrm{V}, 5 \% \mathrm{CO}_{2}$

Cocarboxylase $\mathrm{V}$

$\mathrm{v}$

V

$\mathrm{X}$

None
Habitat and comments

Human respiratory tract, type species

Human conjunctivitis

Prepuce of dogs

Human respiratory tract

Human respiratory tract; haemolytic, but otherwise similar to $H$. influenzae

Human respiratory tract; similar to $H$. parainfluenzae but haemolytic

Fowl respiratory tract (contagious coryza); growth factor requirements not well established (de Blieck, 1931; McGaughey, 1933; Nelson, 1933; Delaplane et al., 1934)

Swine respiratory tract; according to Buchanan et al. (1966) the correct name is

H. influenzae-suis Lewis \& Shope 1931

Fowl respiratory tract

Swine respiratory tract

Swine respiratory tract (porcine contagious pneumonia)

Mouse influenza; requires $\mathrm{X}$ only (Ivanovics \& Ivanovics, 1937)

Acute bacterial endocarditis of man; also human respiratory tract

Human respiratory tract

Human respiratory tract

Ulcer disease of trout

Thromboembolic meningoencephalitis of cattle

Fowl

Human mouth (Kilian, $1976 a$ )

Chancroid in man; fastidious to cultivate

Vaginitis in man

* Species not included in the Approved Lists of Bacterial Names (Skerman et al., 1980).

+ Never validly published.

in the present publication because the chequered history of many of the species requires frequent reference to this information. In Table 2, the type strains as now prescribed by the Approved Lists are marked TAL; it can be seen that several changes in type strains have been made.

Strains received as $H$. ducreyi were difficult to cultivate and for this reason were not included in the present study. Moreover, no strains were available for the species named $H$. citreus (Diernhofer, 1949), H. putoriorum (Hauduroy et al., 1937), H. ovis (Mitchell, 1925) and $H$. agni (Kennedy et al., 1958).

\section{METHODS}

Strains. These are listed in Table 2. Strains were checked for purity and stored as suspensions in basal medium broth (see below) containing $10 \%(\mathrm{v} / \mathrm{v})$ glycerol on beads at $-76^{\circ} \mathrm{C}$ (Feltham et al., 1978). Working cultures were maintained on chocolate agar. This medium was prepared by melting sterile Oxoid blood agar base, cooling it to $75^{\circ} \mathrm{C}$ and adding $6 \%(\mathrm{v} / \mathrm{v})$ sterile horse blood; the whole was then held at $75^{\circ} \mathrm{C}$ and mixed by gentle agitation 
Table 2. Strains studied and their clustering using the $S_{G}$ coefficient (after making the adjustments noted in the text)

\begin{tabular}{|c|c|c|c|c|}
\hline Phenon & Strain no. & Name as received & $\begin{array}{l}\text { Source* and } \\
\text { collection no. }\end{array}$ & Comments ${ }^{\dagger}$ \\
\hline \multirow[t]{44}{*}{1} & $\mathrm{H} 1$ & Haemophilus aegyptius & NCTC 8502 & $\begin{array}{l}\text { TAL. Suggested working } \\
\text { type } \neq \text {; from conjunctiva }\end{array}$ \\
\hline & $\mathrm{H} 2$ & H. aegyptius & NCTC 8134 & From conjunctiva \\
\hline & $\mathrm{H} 3$ & H. aegyptius & NCTC 8135 & From conjunctiva \\
\hline & $\mathrm{H} 4$ & H. aegyptius & NCTC 8134 & From conjunctiva \\
\hline & $\mathrm{H} 7$ & H. influenzae & Kilian HK270 & Biotype III; from conjunctiva \\
\hline & H15 & H. haemoglobinophilus & NCTC 1659 & $\begin{array}{l}\text { TAL. Cotypef; from prepuce } \\
\text { of dog }\end{array}$ \\
\hline & $\mathrm{H} 21$ & H. haemolyticus & NCTC 8479 & Suggested working type $\ddagger$ \\
\hline & H25 & H. haemolyticus & WELL CN 5633 & \\
\hline & $\mathrm{H} 26$ & H. influenzae & NCTC 4560 & Suggested working type $\ddagger$ \\
\hline & $\mathrm{H} 27$ & H. influenzae & NCTC 8468 & Serotype b; from meningitis \\
\hline & $\mathrm{H} 28$ & H. influenzae & NCTC 8466 & Serotype a; from meningitis \\
\hline & H29 & H. influenzae & ATCC 9006 & Serotype a \\
\hline & $\mathrm{H} 30$ & H. influenzae & NCTC 8465 & $\begin{array}{l}\text { Serotype a; from respiratory } \\
\text { infection }\end{array}$ \\
\hline & $\mathrm{H} 31$ & H. influenzae & NCTC 7279 & Serotype $b$; from meningitis \\
\hline & $\mathrm{H} 32$ & H. influenzae & NCTC 8467 & Serotype b; from meningitis \\
\hline & $\mathrm{H} 33$ & H. influenzae & NCTC 8469 & Serotype c; from sputum \\
\hline & $\mathrm{H} 34$ & H. influenzae & NCTC 8470 & Serotype d; from throat \\
\hline & H35 & H. influenzae & NCTC 8472 & Serotype e \\
\hline & $\mathrm{H} 36$ & H. influenzae & NCTC 10479 & Serotype e \\
\hline & $\mathrm{H} 37$ & H. influenzae & NCTC 7918 & $\begin{array}{l}\text { Serotype f; from mastoid } \\
\text { infection }\end{array}$ \\
\hline & $\mathrm{H} 38$ & H. influenzae & RDHL 9 & From oral infection \\
\hline & H39 & H. influenzae & PHLL 27 & From sputum \\
\hline & $\mathrm{H} 40$ & H. influenzae & RIO 2802 & \\
\hline & $\mathrm{H} 41$ & H. influenzae & RIO 73357 & \\
\hline & $\mathrm{H} 42$ & H. influenzae & RIO 72865 & \\
\hline & $\mathrm{H} 43$ & H. influenzae & PHLL CL17 & \\
\hline & $\mathrm{H} 44$ & H. influenzae & PHLL 3545 & \\
\hline & $\mathrm{H} 45$ & H. influenzae & PHLL 43995 & \\
\hline & $\mathrm{H} 46$ & H. influenzae & PHLL 4532 & \\
\hline & H47 & H. influenzae & PHLL 30546 & \\
\hline & $\mathrm{H} 48$ & H. influenzae & Kilian HK 163 & Biotype I; from epiglottis \\
\hline & $\mathrm{H} 49$ & H. influenzae & Kilian HK 177 & Biotype I; from meningitis \\
\hline & $\mathrm{H} 50$ & H. influenzae & Kilian HK 166 & Biotype II; from conjunctivitis \\
\hline & H5 1 & H. influenzae & Kilian HK219 & Biotype II; from sinusitis \\
\hline & $\mathrm{H} 52$ & H. influenzae & Kilian HK209 & Biotype IV; from meningitis \\
\hline & H53 & H. influenzae & Kilian HK343 & Biotype IV \\
\hline & H55 & H. influenzae & Kilian HK233 & Biotype V; from otitis media \\
\hline & H56 & H. influenzae & Kilian HK39 & $\begin{array}{l}\text { Unclassified strain (Kilian, } \\
1976 a \text { ); from pharynx }\end{array}$ \\
\hline & H57 & H. influenzae & Kilian HK281 & $\begin{array}{l}\text { Unclassified strain (Kilian, } \\
1976 a \text { ); from conjunctivitis }\end{array}$ \\
\hline & H58 & H. influenzae & NCTC 8465 & $\begin{array}{l}\text { Serotype a; from respiratory } \\
\text { infection }\end{array}$ \\
\hline & H87 & H. paraphrohaemolyticus & NCTC 10670 & $\begin{array}{l}\text { TAL. Holotype (Zinnemann } \\
\text { et al., 1971); from sputum }\end{array}$ \\
\hline & $\mathrm{H} 88$ & H. paraphrohaemolyticus & NCTC 10671 & $\begin{array}{l}\text { Paratype (Zinnemann et al., } \\
\text { 1971); from sputum }\end{array}$ \\
\hline & H128 & Haemophilus sp. & $\begin{array}{l}\text { PHLL as Johnson } \\
\mathrm{J} 182\end{array}$ & From respiratory tract \\
\hline & H137 & Pasteurella ureae & $\begin{array}{l}\text { PHLL as Johnson } \\
\text { J246 }\end{array}$ & \\
\hline \multirow[t]{5}{*}{2} & H59 & H. suis & NCTC 4557 & TAL of $H$. parasuis. Cotype \\
\hline & $\mathrm{H} 60$ & H. suis & NCTC 6359 & \\
\hline & $\mathrm{H} 61$ & H. suis & NCTC 7440 & \\
\hline & $\mathrm{H} 62$ & H. suis & NCTC 7441 & \\
\hline & H63 & H. suis & BU 5479 & \\
\hline
\end{tabular}


Table 2. (cont.)

Source* and

Phenon Strain no. Name as received

$\begin{array}{ll}\text { H64 } & \text { H. suis } \\ \text { H120 } & \text { H.parasuis } \\ \text { H121 } & \text { H.parasuis } \\ \text { H122 } & \text { H.parasuis } \\ \text { H126 } & \text { H.parasuis }\end{array}$

$\begin{array}{ll}\mathrm{H} 6 & \text { H. influenzae } \\ \mathrm{H} 22 & \text { H. haemolyticus } \\ \mathrm{H} 68 & \text { H.parahaemolyticus } \\ \mathrm{H} 69 & \text { H.parahaemolyticus } \\ \mathrm{H} 70 & \text { H.parahaemolyticus } \\ \mathrm{H} 71 & \text { H.parahaemolyticus } \\ \mathrm{H} 72 & \text { H.parahaemolyticus } \\ \mathrm{H} 73 & \text { H.parahaemolyticus } \\ \mathrm{H} 74 & \text { H.parahaemolyticus } \\ \mathrm{H} 75 & \text { H.parahaemolyticus } \\ \mathrm{H} 76 & \text { H.parahaemolyticus } \\ \mathrm{H} 78 & \text { H.parahaemolyticus } \\ \mathrm{H} 79 & \text { H.parahaemolyticus } \\ \mathrm{H} 80 & \text { H.parahaemolyticus } \\ \mathrm{H} 81 & \text { H.parahaemolyticus } \\ \mathrm{H} 82 & \text { H.parahaemolyticus } \\ \mathrm{H} 86 & \text { H.paraphrophilus } \\ \mathrm{H} 92 & \text { H.parainfluenzae } \\ \mathrm{H} 118 & \text { H.pleuropneumoniae } \\ \mathrm{H} 119 & \text { H.pleuropneumoniae }\end{array}$

\begin{tabular}{|c|c|}
\hline $\begin{array}{l}\mathrm{H} 24 \\
\mathrm{H} 66 \\
\mathrm{H} 67 \\
\mathrm{H} 83\end{array}$ & $\begin{array}{l}\text { H. haemolyticus } \\
\text { H. parahaemolyticus } \\
\text { H. parahaemolyticus } \\
\text { H. paraphrophilus }\end{array}$ \\
\hline H84 & H. paraphrophilus \\
\hline H85 & H. paraphrophilus \\
\hline H89 & H. paraphrohaemolyticus \\
\hline $\begin{array}{l}\mathrm{H} 90 \\
\mathrm{H} 93 \\
\mathrm{H} 94 \\
\mathrm{H} 95 \\
\mathrm{H} 98 \\
\mathrm{H} 100 \\
\mathrm{H} 102 \\
\mathrm{H} 108\end{array}$ & $\begin{array}{l}\text { H. parainfluenzae } \\
\text { H. parainfluenzae } \\
\text { H. parainfluenzae } \\
\text { H. parainfluenzae } \\
\text { H. parainfluenzae } \\
\text { H. parainfluenzae } \\
\text { H. parainfluenzae } \\
\text { H. gallinarum }\end{array}$ \\
\hline $\begin{array}{l}\text { H115 } \\
\text { H116 }\end{array}$ & $\begin{array}{l}\text { H. segnis } \\
\text { H. segnis }\end{array}$ \\
\hline $\begin{array}{l}\text { H91 } \\
\text { H96 } \\
\text { H104 }\end{array}$ & $\begin{array}{l}H . \text { parainfluenzae } \\
H . \text { parainfluenzae } \\
H . \text { parainfluenzae }\end{array}$ \\
\hline
\end{tabular}

H105

Haemophilus sp.

H106 H.parainfluenzae

$\mathrm{H} 107 \quad H$.gallinarum

H112 H. gallinarum
CCM 5747
BU A 9
BU C5
BU B26
CCM 5749

Kilian $\mathrm{HK} 7$

NCTC 10659

BU Shope

BU K 17

BU Shope

BU 1536

BU 1421

CCM 5630

CCM 5869

CCM 5870

CCM 5871

BU 4074

ATCC 27088

ATCC 27089

ATCC 27090

ATCC 27088

Kilian HK83

ATCC 7901

NCTC 10976

Kilian HK36 1

RDHL 2

RDHL 58

RDHL 17

NCTC 10557

NCTC 10556

NCTC 10558

NCTC 10672

NCTC 7857

ATCC 9796

NCTC 10665

RDHL 22

BCH 236

Kilian HK47

Kilian HK19

LEEDS as

ATCC 14385

Kilian HK307

Kilian HK87

NCTC 4101

NCTC 4101

Kilian HK408

Kilian HK 164

ATCC 9796

NCTC 3438

HPRS 2561 collection no.

Commentst
Biotype III: from pharynx

TAL. From sputum

Serotype 1

Serotype 1 (Shope, 1964)

Serotype 2

Serotype 3

Serotype 1

Serotype 2

Serotype 3

Serotype 1

Serotype 1

Serotype 2

Serotype 3

Serotype 1

From saliva

Serotype 2

Serotype 2; from swine

pleuropneumonia

From tooth abscess

From tooth surface

From tooth abscess

TAL. Holotype (Zinnemann et al., 1968)

Cotype (Zinnemann et al.,

1968); from parietal abscess

Cotype (Zinnemann et al.,

1968); from trachea

Paratype (Zinnemann et al., 1971)

TAL

Biotype III; from saliva

From tooth surface

Biotype 1; from pharynx

Biotype III; from pharynx

From dental plaque

From saliva

From tongue

From tongue

Unclassified strain (Kilian, 1976a); NCTC 4101 from tongue

Taxon A (Kilian, 1976a);

from conjunctivitis

From fowl respiratory tract

From fowl 
Table 2. (cont.)

$\begin{array}{ccl}\text { Phenon } & \text { Strain no. } & \text { Name as received } \\ 6 & \mathrm{H} 109 & \text { H.gallinarum } \\ & \mathrm{H} 110 & \text { H.gallinarum } \\ \mathrm{H} 111 & \text { H.gallinarum } \\ \mathrm{H} 123 & \text { H.parasuis } \\ \mathrm{H} 124 & \text { H.parasuis } \\ \mathrm{H} 125 & \begin{array}{l}\text { H.parasuis } \\ \mathrm{H} 140\end{array} & \text { H.avium } \\ \mathrm{H} 141 & \begin{array}{l}\text { H.avium } \\ \text { H.avium }\end{array} \\ \mathrm{H} 142 & \begin{array}{l}\text { H.avium } \\ \text { Hctinobacillus lignieresii }\end{array} \\ & \mathrm{H} 131 & \text { Pasteurella multocida } \\ \text { H132 } & \text { Haemophilus } \\ & \text { influenzae-murium }\end{array}$

8

H144 H.paragallinarum

H145 H.paragallinarum

H146 H.paragallinarum

H147 H. paragallinarum

H150 H. somnus

H151 H. somnus

H152 H. somnus

H153 H. somnus

H154 H. somnus

H155 H. somnus

H156 H. somnus

H157 H. somnus

9

\section{$\mathrm{H} 8 \quad H$. influenzae}

H9 H. aphrophilus

H10 H. aphrophilus

$\mathrm{H} 11 \quad$ H. aphrophilus

$\mathrm{H} 12$ H. aphrophilus

$\mathrm{H} 13$ H. aphrophilus

10

H133 Pasteurella pneumotropica

H134 P. haemolytica A

H135 P. haemolytica var. ureae

H136 P. ureae

H130 Actinobacillus lignieresii

H139 A. equuli

H159 Haemophilus piscium

H160 H.piscium

H161 Fish isolate
Source* and collection no.

CCM 5015

CCM 5066

CCM 5080

CCM 5111

CCM 5113

CCM 5114

Hinz K2654

Hinz K2659

Hinz K94

Hinz K64

Johnson $\mathbf{J} 20$ as

NCTC 4975

Johnson $\mathbf{J} 167$ as

NCTC 3195

HCC 95001

Hinz K2403

Hinz K2671

Hinz K 1676

Hinz K 1645

Bailie 3411

Bailie 2260

MAFF 91

MAFF 92

Bailie 5075

Bailie 3409

Bailie 2830

Bailie 4060

Kilian HK294

NCTC 5908

NCTC 5886

CIP 5961

CIP 6473

CIP 6811

Johnson J169 as

NCTC 8141

Johnson J171 as

NCTC 10365

NCTC 10219

Johnson $\mathbf{J} 170$ as

NCTC 10222

Johnson $\mathbf{J} 20$ as

NCTC 4975

Johnson $\mathbf{J} 19$ as

NCTC 8529

ATCC 15711

ATCC 14362

Weymouth 145

\section{Comments ${ }^{\dagger}$}

Taxon C (Kilian, 1976a);

from fowl

Taxon C (Kilian, 1976a);

from fowl

Taxon C (Kilian. 1976a); from fowl

Taxon C (Kilian, 1976a);

from swine pneumonia

Taxon C (Kilian, 1976a);

from swine pneumonia

From swine pneumonia

TAL. Type strain ATCC 29546 (Hinz \& Kunjara,

1977): from sinus of fowl

From fowl lung

From sinus of fowl

From airsac of fowl

Suggested working type:

From mouse pneumonia

TAL. From sinus of fowl

From sinus of fowl

From sinus of fowl

From sinus of fowl

From bovine meningitis

From bovine meningitis

From bovine meningitis

From bovine meningitis

From bovine meningitis

From bovine meningitis

From bovine meningitis

From bovine meningitis

Biotype III; from conjunctivitis

TAL. From endocarditis

Holotypef; from endocarditis

TAL

TAL of $P$. ureae

TAL. Suggested working type $\ddagger$

Authentic strain (Snieszko et al., 1950); from trout ulcer Authentic strain (Snieszko et al., 1950); from trout ulcer From trout 


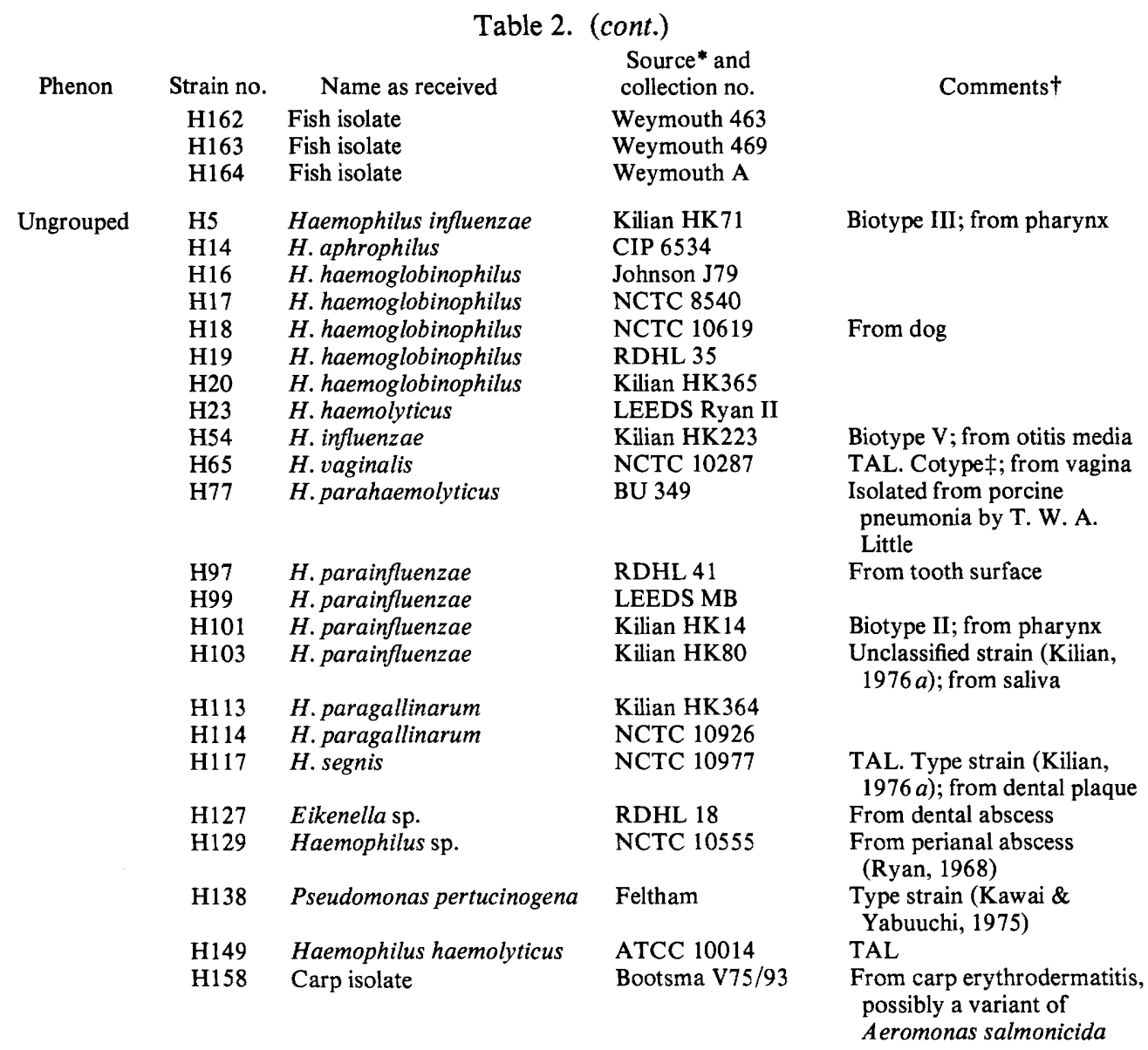

\footnotetext{
* Sources: ATCC, American Type Culture Collection, Rockville, Maryland, U.S.A.; Bailie, W. E. Bailie, College of Veterinary Medicine, Manhatton, Kansas, U.S.A.; BCH, R. H. George, Department of Microbiology, The Children's Hospital, Birmingham, U.K.; Bootsma, R. Bootsma, Vakgroep Pathologie, Utrecht, Netherlands; BU, J. Nicolet, University of Berne, Switzerland; CCM, Czechoslovak Collection of Microorganisms, Brno, Czechoslovakia; CIP, Collection de l'Institut Pasteur, Paris, France; Feltham, R. K. A. Feltham, Department of Microbiology, University of Leicester, U.K.; HCC, Hungarian National Collection of Medical Bacteria, Budapest, Hungary; Hinz, K.-H. Hinz, Institut für Geflungelkrankheiten, Hanover, Germany; HPRS, E. G. Harry, Houghton Poultry Research Station, Cambridge, U.K.; Johnson, R. Johnson, Department of Microbiology, University of Leicester, U.K.; Kilian, M. Kilian, Department of Microbiology, Royal Dental College, Aarhus, Denmark; LEEDS, J. Frazer, Department of Microbiology, University of Leeds Medical School, U.K.; MAFF, Ministry of Agriculture, Fisheries and Food, Weybridge, Surrey, U.K.; NCTC, National Collection of Type Cultures, Colindale, London, U.K.; PHLL, Public Health Laboratory, Leicester, U.K.; RDHL, W. Sims, Royal Dental Hospital, London, U.K.; RIO, D. C. Turk, Bacteriology Department, Radcliffe Infirmary, Oxford, U.K.; WELL, Wellcome Research Laboratories, Beckenham, Kent, U.K.; Weymouth, A. W. Salisbury, M.A.F.F., Weymouth, Dorset, U.K.

$\dagger$ TAL indicates a type strain in the Approved Lists of Bacterial Names (Skerman et al., 1980). Serotypes a-f are those of Pittman (1931). Serotypes 1-3 are those of Nicolet (1971) and Kilian et al. (1978). The biotypes are those of Kilian $(1976 a)$.

† Sneath \& Skerman (1966).
}

for about $10 \mathrm{~min}$ or until the blood became chocolate brown. Strain $\mathrm{H} 158$ required a specialized maintenance medium (R. Bootsma, personal communication) consisting of Oxoid tryptose blood agar base with $10 \%(\mathrm{v} / \mathrm{v})$ sterile horse serum.

Basal medium. The colourless basal medium (BM) contained: Oxoid nutrient broth no. 2, 920 ml; NAD ( $250 \mathrm{mg} \mathrm{l}^{-1}$ aqueous solution), $10 \mathrm{ml}$; haematin $\left(250 \mathrm{mg} \mathrm{l}^{-1}\right.$ solution in $\left.10 \mathrm{~mm}-\mathrm{NaOH}\right), 10 \mathrm{ml}$; cocarboxylase 
(200 $\mathrm{mg} \mathrm{l}^{-1}$ aqueous solution), $10 \mathrm{ml}$; Difco sterile horse serum, $50 \mathrm{ml}$. Solutions were sterilized by membrane filtration ( $220 \mathrm{~nm}$ pore size). BM agar was prepared by adding $1.5 \%(\mathrm{w} / \mathrm{v})$ Oxoid agar no. 3 .

Standard cultural conditions. Except where stated, stock cultures and tests were incubated at $37{ }^{\circ} \mathrm{C}$ in $5-10 \%$ (v/v) $\mathrm{CO}_{2}$ in air. Strains $\mathrm{H} 158$ to $\mathrm{H} 164$ were incubated at $25^{\circ} \mathrm{C}$ in air. Initially, the $\mathrm{CO}_{2}$ was obtained using Beogex Suppositories (Pharmax, Bexley, Kent) and disposable $\mathrm{CO}_{2}$ generator envelopes (Becton, Dickinson Co., Wembley, Middx.); later, a $\mathrm{CO}_{2}$ incubator (Continuous Flow Type GFC) was used. The standard inoculum was one loopful of $24 \mathrm{~h}$ culture on maintenance medium suspended in BM to give the same turbidity as tube no. 2 on the MacFarland scale. When media were supplemented with $\mathrm{X}$ factor, $\mathrm{V}$ factor and cocarboxylase, the final concentrations were, respectively, $2 \cdot 5,2 \cdot 5$ and $2 \cdot 0 \mathrm{mg} \mathrm{l}^{-1}$.

Colonial and cell morphology. Strains grown on chocolate agar were examined for colonial features after $24 \mathrm{~h}$ ( $48 \mathrm{~h}$ for more slowly growing strains). Heat-fixed films of $24 \mathrm{~h}$ cultures were stained by Burke's modification of Gram's stain (Cruikshank et al., 1975) with $2 \%(\mathrm{w} / \mathrm{v})$ aqueous safranine as the counterstain.

Growth at different temperatures. Strains were incubated on chocolate agar at $4,25,30,37$ and $45{ }^{\circ} \mathrm{C}$ and growth was recorded at $7 \mathrm{~d}$ for $4{ }^{\circ} \mathrm{C}$ and $3 \mathrm{~d}$ for the other temperatures.

Growth in different atmospheres. Chocolate agar plates were inoculated and incubated in air, in $5-10 \% \mathrm{CO}_{2}$ in air, and anaerobically. Growth was recorded after $48 \mathrm{~h}$.

Growth on routine media. Nutrient agar (Oxoid) and MacConkey agar (Oxoid) plates were inoculated with a loopful of $24 \mathrm{~h}$ culture in BM medium, and examined after $48 \mathrm{~h}$. Growth on horse blood agar was determined after $48 \mathrm{~h}$ incubation on BM agar containing $10 \%(\mathrm{v} / \mathrm{v})$ sterile horse blood in the top layer. Haemolysis of horse, sheep and rabbit blood on layered BM agar was recorded at $48 \mathrm{~h}$. Although $\beta$-haemolysis was readily detected, diffuse and incomplete haemolysis (usually of a greenish brown tinge) was seen with many strains - this is referred to as 'greening'.

Growth factor requirements. Cultures were plated on BM agar and BM agar supplemented with haematin $\left(2.5 \mathrm{mg} \mathrm{l}^{-1}\right)$, NAD $\left(2.5 \mathrm{mg}^{-1}\right)$, haematin and NAD (both $\left.2.5 \mathrm{mg}^{-1}\right)$ or cocarboxylase $\left(2.0 \mathrm{mg} \mathrm{1}^{-1}\right)$; growth was recorded after $48 \mathrm{~h}$.

The presence of enzymes for converting added $\delta$-aminolaevulinic acid to porphyrins ( $\delta$-ALA test) was examined by the method of Kilian (1974); a positive result was a pink coloration in the test solution (indicating the presence of porphyrins); a negative result indicated $\mathrm{X}$-dependence.

Motility. This was examined by the method of Craigie (1931) using semi-solid BM containing $0.25 \%$ (w/v) Oxoid agar no. 3, and looking for spreading growth after $48 \mathrm{~h}$.

Biochemical tests. Urease production was determined after $48 \mathrm{~h}$, using a modification of Christensen's medium (Cowan, 1974) with added X, V and cocarboxylase. Oxidase activity was tested by the method of Kovacs (1956) with $24 \mathrm{~h}$ cultures on chocolate agar. Catalase activity was tested by adding $\mathrm{H}_{2} \mathrm{O}_{2}$ ( 20 vol.) dropwise to $24 \mathrm{~h}$ plate cultures on BM agar, and noting effervescence. Nitrate reduction in BM broth cultures to which $0 \cdot 1 \%(\mathrm{w} / \mathrm{v})$ $\mathrm{KNO}_{3}$ had been added was tested after $5 \mathrm{~d}$ incubation by the method of Wilson \& Miles (1964): negative results were checked by adding $\mathrm{Zn}$ dust. Activity in the ONPG test was determined after $24 \mathrm{~h}$ in liquid medium (Cowan, 1974) with added $X, V$ and cocarboxylase.

For the methyl red and Voges-Proskauer tests, the medium contained $0.5 \%(\mathrm{w} / \mathrm{v})$ Oxoid peptone, $0.5 \%(\mathrm{w} / \mathrm{v})$ $\mathrm{KH}_{2} \mathrm{PO}_{4}, 0.5 \%(\mathrm{w} / \mathrm{v})$ glucose and the standard amounts of $\mathrm{X}, \mathrm{V}$ and cocarboxylase. Cultures were tested after $72 \mathrm{~h}$ by adding methyl red. Acetoin production (the Voges-Proskauer reaction) was determined in the same tubes by adding $0.5 \mathrm{ml} 1 \%(\mathrm{w} / \mathrm{v}) \alpha$-naphthol and $1 \mathrm{ml} 40 \%(\mathrm{w} / \mathrm{v}) \mathrm{NaOH}$ : a positive reaction was indicated by a deep red coloration after $4 \mathrm{~h}$.

Indole production was tested in BM broth cultures after $48 \mathrm{~h}$ by adding $0.5 \mathrm{ml}$ Kovacs' indole reagent (Cowan, 1974). Hydrogen sulphide production from peptone was tested in BM cultures after $48 \mathrm{~h}$ with lead acetate indicator paper. Gelatin hydrolysis was tested after $72 \mathrm{~h}$ on BM agar with $4 \mathrm{~g}$ gelatin $\mathrm{l}^{-1}$ by flooding the plates with the reagent of Frazier (1926). Tyrosine and xanthine hydrolysis were determined by the methods of Gordon \& Smith (1955). Aesculin hydrolysis was detected by a dark coloration after $48 \mathrm{~h}$ on BM agar containing $0.05 \%(\mathrm{w} / \mathrm{v})$ ferric ammonium citrate and $0.5 \%(\mathrm{w} / \mathrm{v})$ aesculin. Casein hydrolysis was detected on $\mathrm{BM}$ agar with $20 \%(\mathrm{w} / \mathrm{v})$ sterile skim milk (Oxoid) by examining for zones of clearing for up to $14 \mathrm{~d}$. Hydrogen cyanide production was determined on $\mathrm{BM}$ agar with an extra $5 \%(\mathrm{v} / \mathrm{v})$ sterile horse serum by the method of Sneath (1956), using picric acid/sodium carbonate indicator papers (Sneath, 1966). Deoxyribonuclease activity was tested after $48 \mathrm{~h}$ by the method of Smith et al. (1969) using DNAase agar (Difco) with added growth factors.

The utilization of mucate, gluconate, pectate, citrate, malonate and acetate was determined in API 50E galleries (API, Farnborough, Hants.) and read after $48 \mathrm{~h}$ according to the manufacturer's instructions. To examine the oxidative-fermentative utilization of glucose, the medium of Hugh \& Leifson (1953) with added X, V and cocarboxylase was used and tests were read after $72 \mathrm{~h}$.

Other enzyme activities were investigated using the API-ZYM system. Overnight cultures on chocolate agar were suspended in sterile distilled water to give a turbidity between that of tubes no. 5 and no. 6 on the MacFarland scale, and added to the cupules. After $4 \mathrm{~h}$ at $37^{\circ} \mathrm{C}$ the test reagent, made up according to the manufacturer's 
instructions, was added. The plates were left for $10 \mathrm{~min}$ under intense light, and then read and scored according to the API standard colour chart. The enzyme activities are recorded in Table 4, tests 40-58. Lipase and tetrathionate reductase (tests 135,136 ) were determined in API $50 \mathrm{E}$ galleries after $48 \mathrm{~h}$ according to the manufacturer's instructions.

Production of acid from carbohydrates. API 50E galleries were used for 39 carbohydrate fermentations (Table 4, tests 70-106, and dulcitol and amylose). Growth from overnight chocolate agar cultures was emulsified in Difco nutrient broth with added factors to give a suspension with the same turbidity as tube no. 2 on the MacFarland scale. The cupules were inoculated with bacterial suspension and the galleries were read at $3,6,24$ and $48 \mathrm{~h}$. The results obtained by this method were compared with those obtained with Replidishes (Sterilin, Teddington, Middx.), inoculated as described by Stevens (1969), in the following medium (modified from Hugh \& Leifson, 1953): Oxoid Lab Lemco, $1 \mathrm{~g}$; Oxoid peptone, $1 \mathrm{~g} ; \mathrm{NaCl}, 1 \mathrm{~g} ; \mathrm{KH}_{2} \mathrm{PO}_{4}, 0.3 \mathrm{~g}$; Oxoid agar no. 3, $5 \mathrm{~g}$; bromothymol blue $(0.2 \%$, w/v, aqueous solution), $15 \mathrm{ml}$; distilled water, $820 \mathrm{ml}$, to which was added horse serum, $50 \mathrm{ml}$; carbohydrate $(10 \%, \mathrm{w} / \mathrm{v}$, aqueous solution $), 100 \mathrm{ml}$; and $\mathrm{X}, \mathrm{V}$ and cocarboxylase. The results were read after 1, 2, 3, 5 and $7 \mathrm{~d}$. An alkaline reaction in the medium containing dulcitol (which was not acidified by any strain) was also recorded if it occurred (test 107).

Tolerance to heat and chemical inhibitors. Growth was observed on BM agar containing 0, 0.5, 1.0, 3.0, 5.0 and $10 \%(\mathrm{w} / \mathrm{v}) \mathrm{NaCl}$ after $48 \mathrm{~h}$. In addition, the stimulatory effect of $0.5 \% \mathrm{NaCl}$ was recorded for cultures incubated in air. To examine resistance to heat, overnight $\mathrm{BM}$ cultures were heated to $56^{\circ} \mathrm{C}$, and samples were removed after $0,5,10,15$ and $20 \mathrm{~min}$ to chocolate agar which was examined for growth after $24 \mathrm{~h}$. Growth on chocolate agar containing potassium tellurite $\left(320 \mathrm{mg} \mathrm{l}^{-1}\right)$ or sodium azide $\left(72 \mathrm{mg} \mathrm{l}^{-1}\right)$ was examined after $48 \mathrm{~h}$. Growth on BM agar containing $0.1 \%(\mathrm{w} / \mathrm{v})$ phenol was examined after $48 \mathrm{~h}$.

Antibiotic sensitivity. Sensitivity to antibiotics was examined on chocolate agar plates poured to a depth of $5 \mathrm{~mm}$. A loopful of growth from a $24 \mathrm{~h}$ agar culture was emulsified in $2.5 \mathrm{ml}$ sterile saline and poured on to each chocolate agar plate. The excess liquid was removed with a sterile Pasteur pipette and then the plates allowed to stand for $30 \mathrm{~min}$ before the antibiotic discs were placed aseptically on to the surface. The plates were dried and incubated at $37^{\circ} \mathrm{C}$ for $48 \mathrm{~h}$. The zone of growth inhibition was measured. The antibiotics (Multodisks, Oxoid) and quantity per disc were: chloramphenicol, 10 and $50 \mu \mathrm{g}$; chlortetracycline, $10 \mu \mathrm{g}$; furazolidone, $50 \mu \mathrm{g}$; neomycin, $10 \mu \mathrm{g}$; oxytetracycline, $10 \mu \mathrm{g}$, penicillin G, 1.5 and 5 units; streptomycin, 10 and $25 \mu \mathrm{g}$; sulphafurazole, 100 and $500 \mu \mathrm{g}$; ampicillin, $25 \mu \mathrm{g}$; cephaloridine, $25 \mu \mathrm{g}$; carbenicillin, $100 \mu \mathrm{g}$; colistin sulphate, $10 \mu \mathrm{g}$; gentamicin, $10 \mu \mathrm{g}$; co-trimoxazole, $25 \mu \mathrm{g}$; tetracycline, $50 \mu \mathrm{g}$; erythromycin, $50 \mu \mathrm{g}$; novobiocin, $30 \mu \mathrm{g}$; oleandomycin, $10 \mu \mathrm{g}$.

Numerical taxonomy. The computing was performed on the University of Nottingham's ICL 1900 computer and the University of Leicester's CDC CYBER 72 computer, using programs written by M. J. Sackin and associates of the Microbiology Department, Leicester University.

The $t \times n$ matrix was composed of 164 strains and 141 characters. Two-state characters were scored 0 for negative and 1 for positive, Multi-state characters were scored 0 for negative and 1, 2 for weak and strong positive, respectively. Sensitivity to antibiotics was scored according to the radius of the zone of inhibition around the disc: $<1 \mathrm{~mm}=0,1-4 \mathrm{~mm}=1,4-8 \mathrm{~mm}=2,>8 \mathrm{~mm}=3$. The API-ZYM enzyme tests were scored according to the manufacturer's scale of $0-5$. The API $50 \mathrm{E}$ tests were scored after $48 \mathrm{~h}$ incubation and the numbers on the manufacturer's scale of $0-5$ were then converted to scores for numerical taxonomy: $0-1=0,2-3=1,4-5=2$. To give the percentages in Table 4, scores of 0 were taken as negative and 1 or more as positive, except for the API-ZYM and API 50E tests, for which $0-1$ was scored as negative and 2-5 as positive.

The similarity coefficients used were the Gower coefficient $\left(S_{G}\right)$ and the pattern coefficient $\left(S_{p}\right)$ with cluster analysis by average linkage (UPGMA) and single linkage. The vigour coefficient of each strain was also calculated. Details of these methods are given in Sneath \& Sokal (1973). The scores were all converted to positive and negative for the pattern and vigour coefficients and for the $S_{S M}$ values in Table 3, by using the scoring in Table 4 . Test reproducibility was taken into consideration by duplicating six strains. The pairs were: $\mathrm{H} 2, \mathrm{H} 4 ; \mathrm{H} 30, \mathrm{H} 58$; H68, H70; H91, H96; H93, H106; H130, H131.

RESULTS

\section{Numerical taxonomy}

Test reproducibility. The results for the six duplicated strains showed that carbohydrate fermentations in Replidishes were somewhat less reproducible than those in API 50E kits. For this reason the Replidish results were omitted from the computations, leaving 141 characters. The resulting similarities between the duplicate strains ranged from 84.0 to $97.1 \%$ (average $89.2 \%$ ) for $S_{G}$ and from 85.0 to $98.0 \%$ (average $90.3 \%$ ) for $S_{P}$. This corresponds to about $5 \%$ test error (or rather less if differences in quantitative characters are discounted) which is acceptable (Sneath \& Johnson, 1972). 
Gower coefficient, $S_{G}(\%)$

60 70 80 90 100
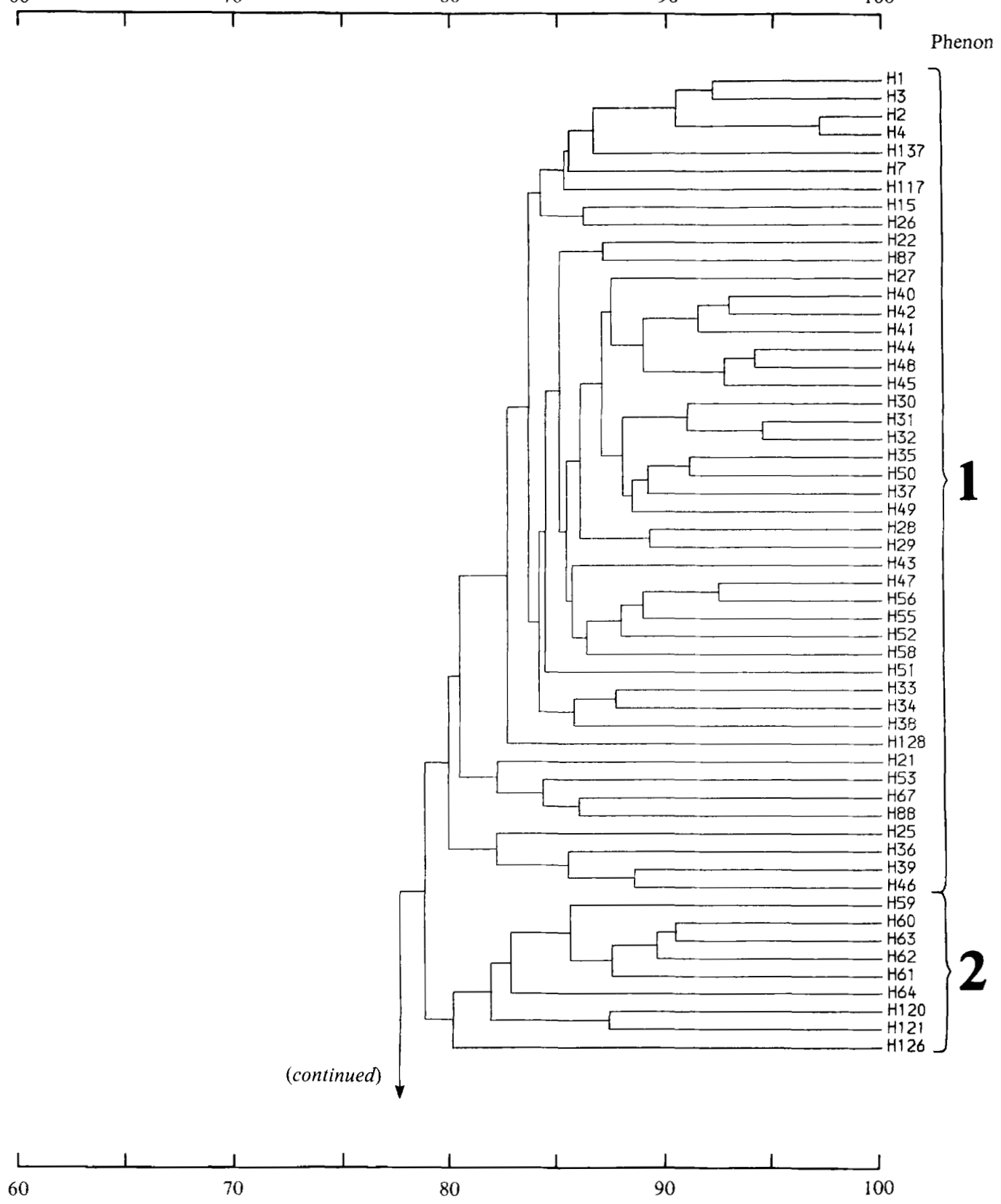

Fig. 1. Dendrogram of 164 strains of Haemophilus and related bacteria by UPGMA with Gower's coefficient $\left(S_{G}\right)$. The cophenetic correlation was $0 \cdot 82$. 
Gower coefficient, $S_{G}(\%)$

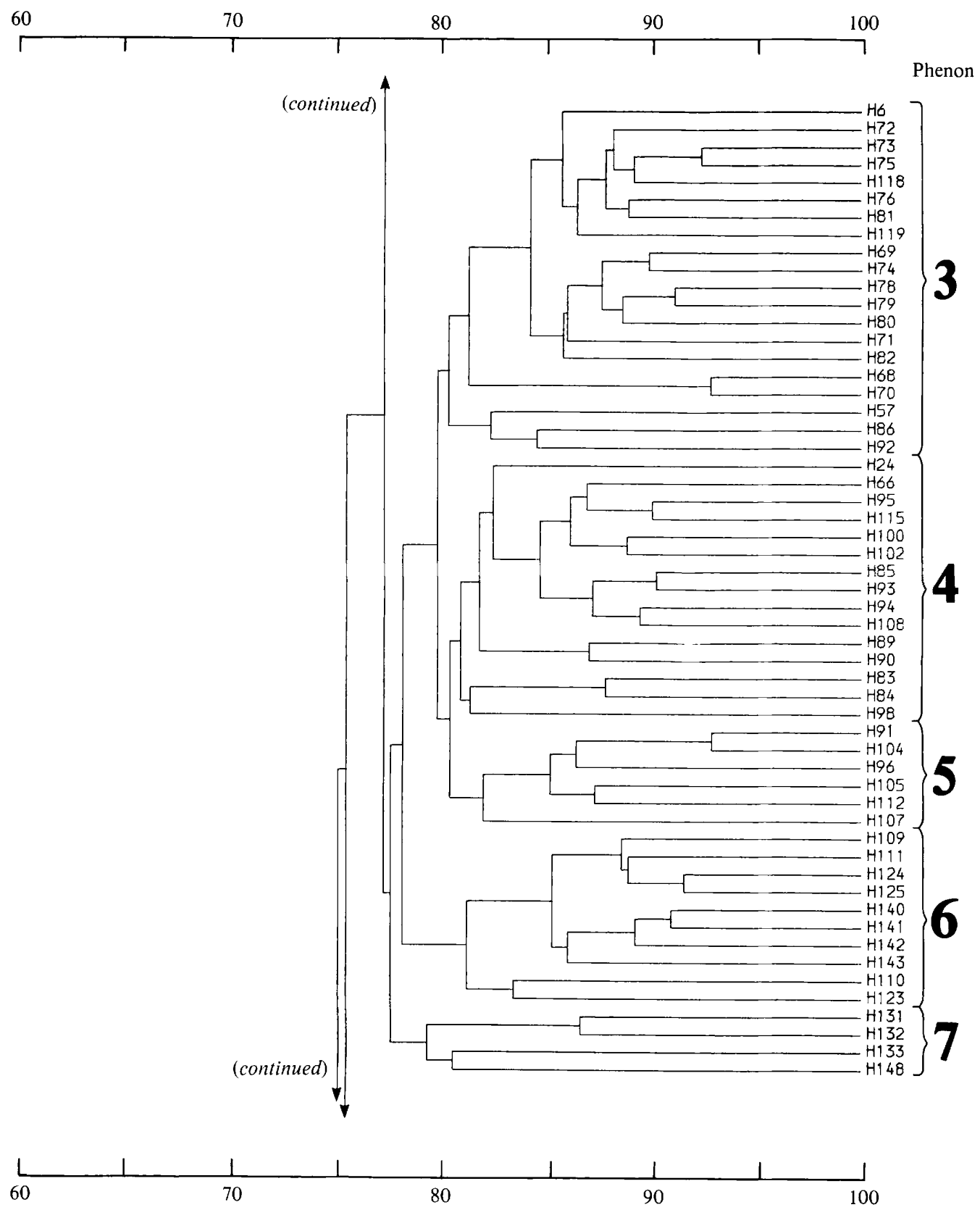

Fig. 1 (continued) 
Gower coefficient, $S_{G}(\%)$

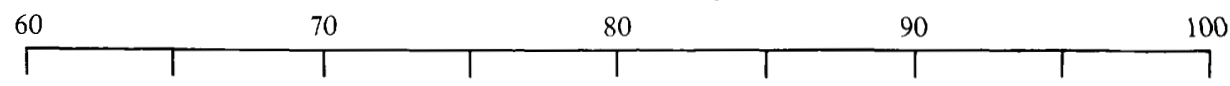
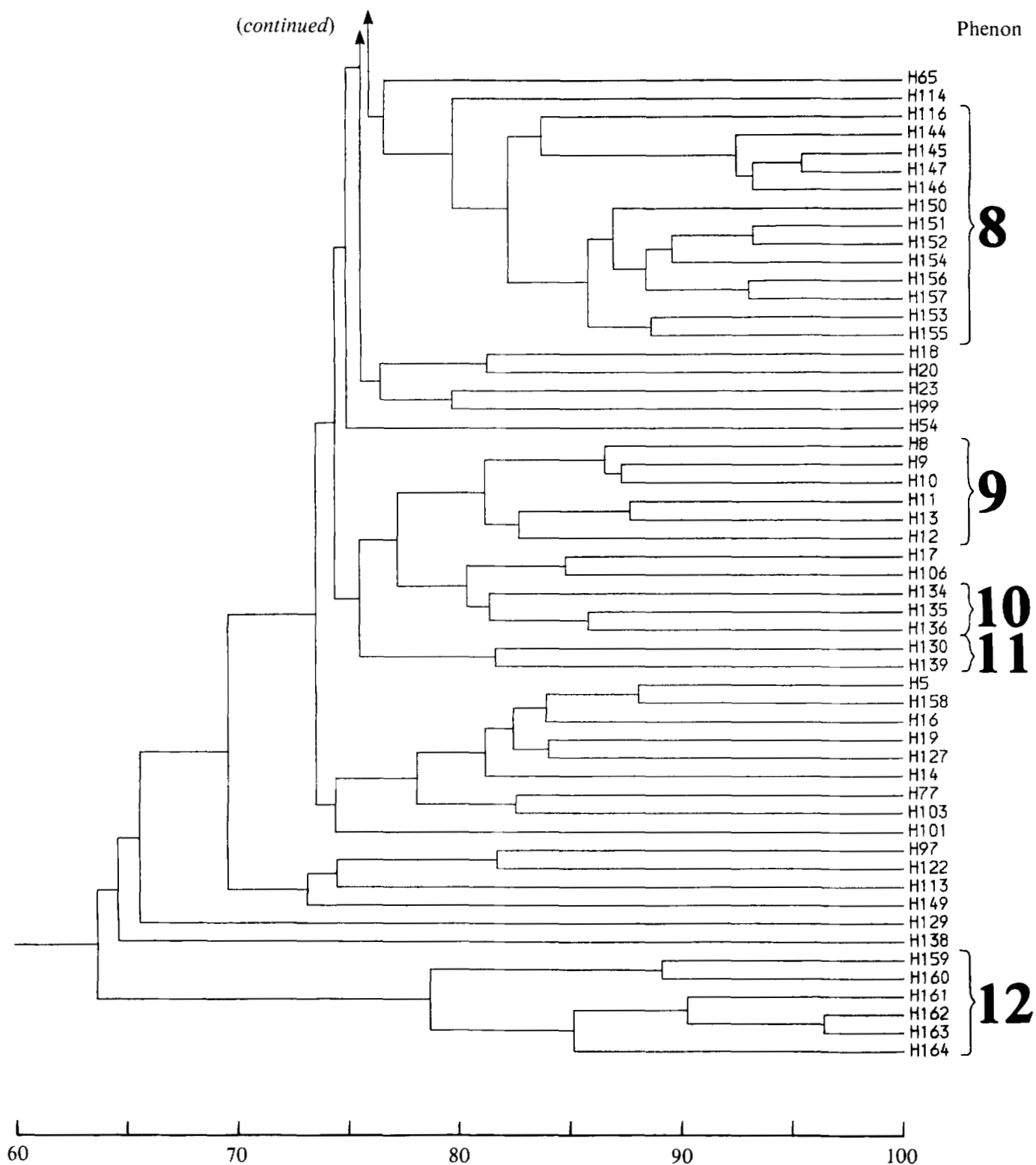

Fig. 1 (continued) 


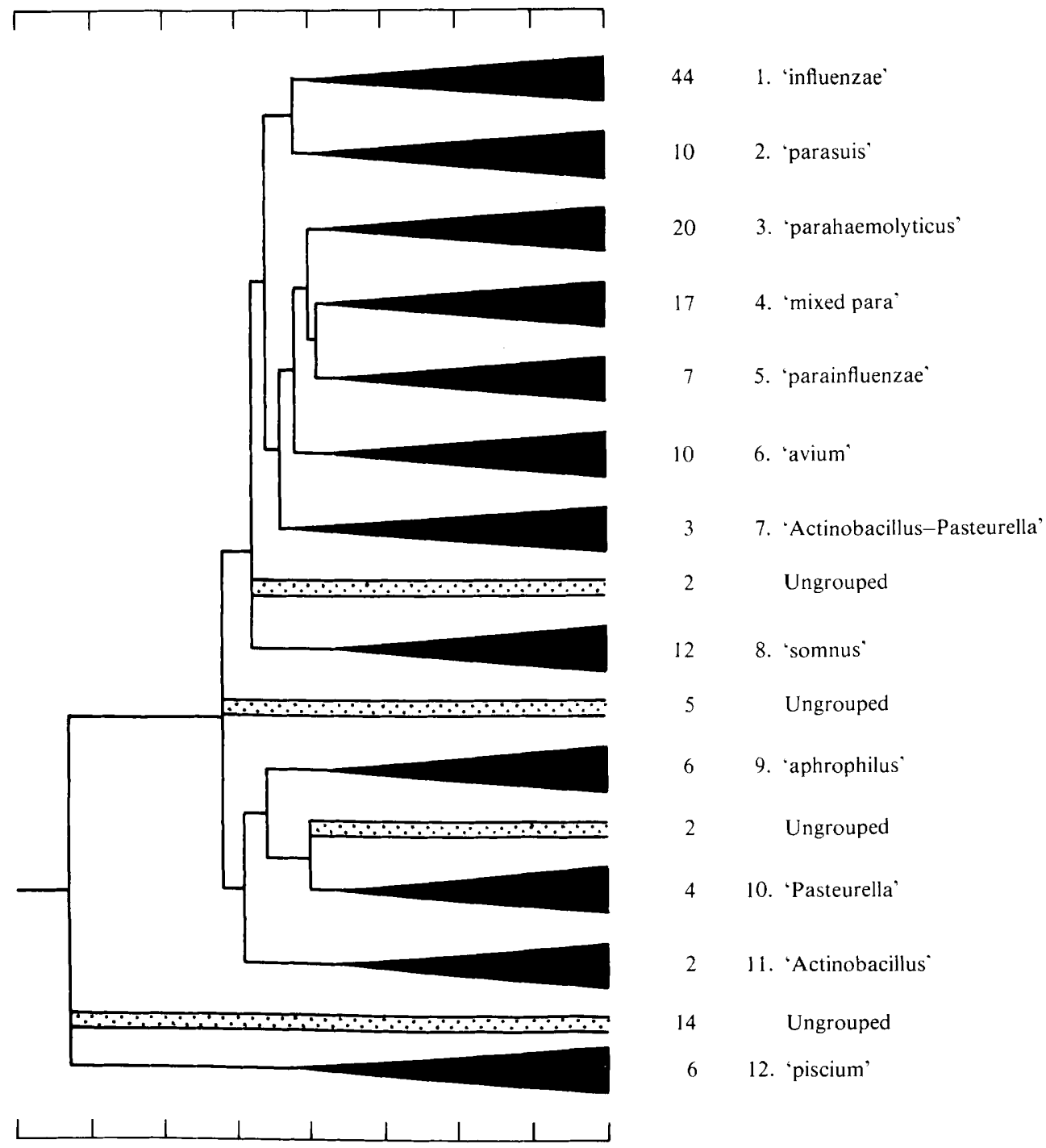

Fig. 2. Simplified dendrogram from Fig. 1 based on $S_{G}$ and UPGMA clustering. The numbers of strains in the phenons are those after making the adjustments noted in the text.

Cluster analysis. The results of the different computations gave broadly similar groupings. The taxonomy described below is based on the well-tried technique of UPGMA clustering on the Gower coefficient (Figs 1, 2), with reference to the dendrogram (Fig. 3) from the less-used pattern coefficient as required. One hundred and forty of the strains fell into 12 clusters (Fig. 1). Salient relations are shown in the simplified dendrogram (Fig. 2). Single linkage clustering gave similar but less clear-cut results than UPGMA.

After considering the results from the UPGMA analysis on the pattern coefficient (Fig. 3; cophenetic correlation 0.78 ), a small number of strains were moved to other phenons. These strains are mentioned below in the descriptions of the phenons and are shown in their 


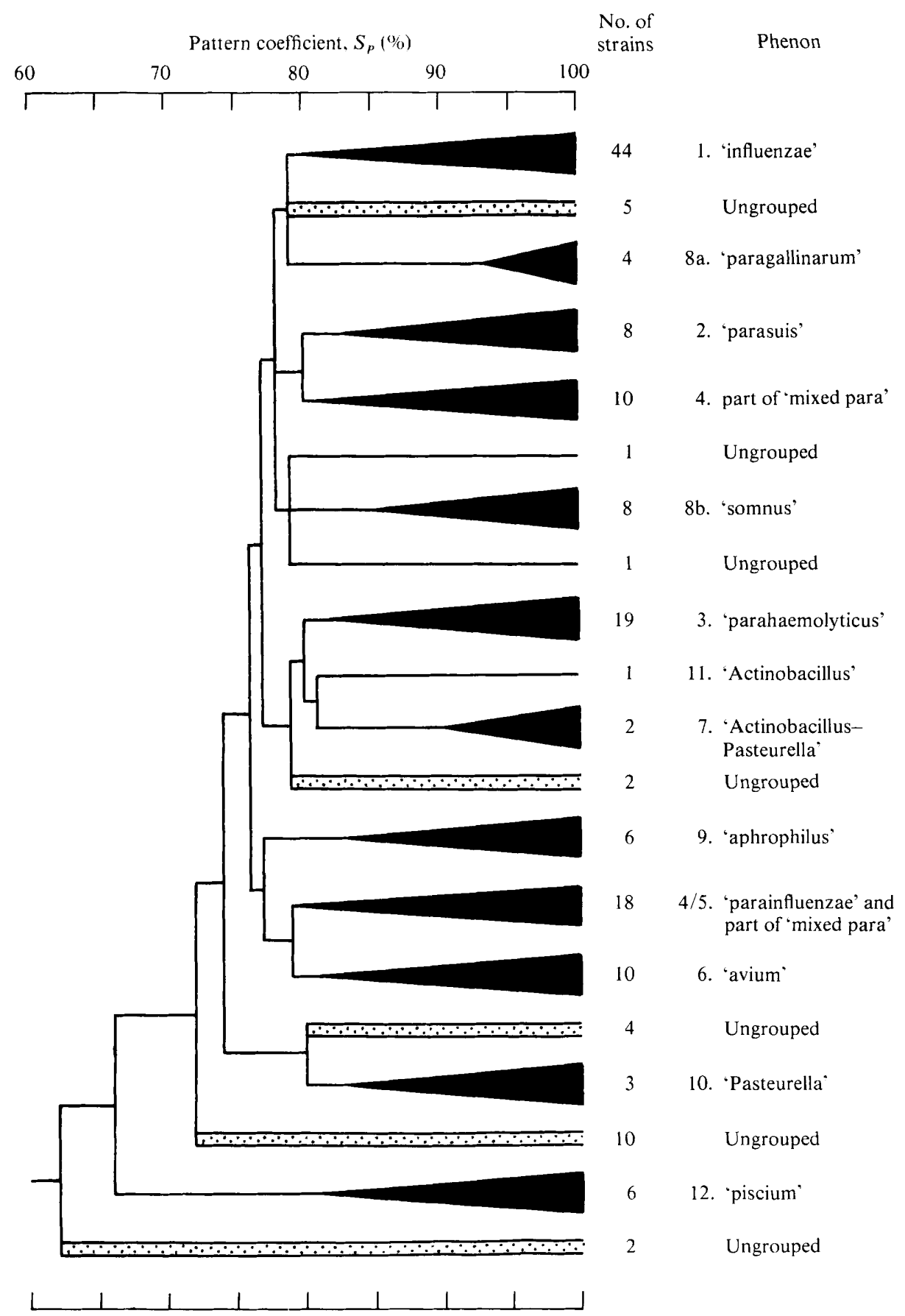

Fig. 3. Simplified dendrogram based on the pattern coefficient $\left(S_{P}\right)$ and UPGMA clustering.

$S_{p}$ /UPGMA positions in Table 2. For the amended phenons the mean intergroup and intragroup similarities, and mean vigour coefficients, were calculated (Table 3 ), and also the percentages of positive test results shown in Table 4. 


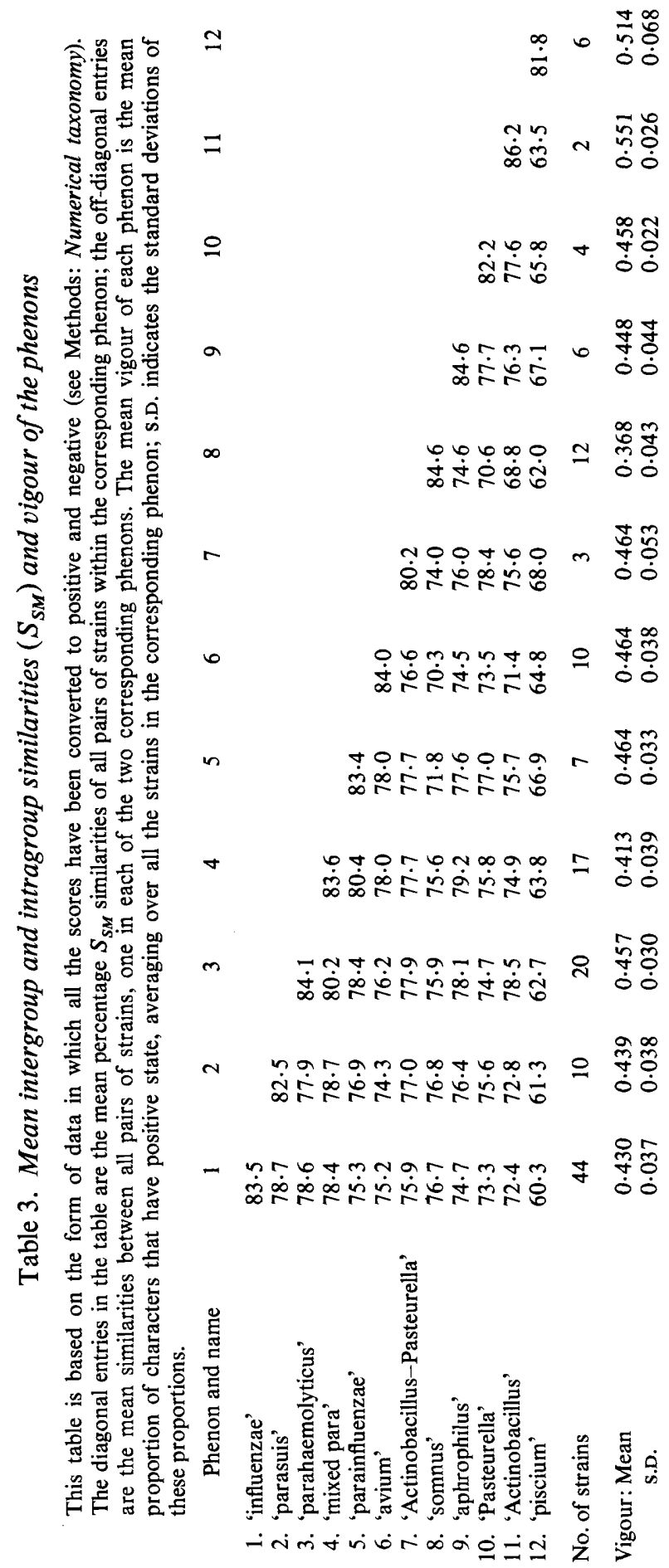


Description of the phenons

Phenon 1 (the 'influenzae' cluster) contained most of the strains that required both $\mathrm{X}$ and V. The majority were non-haemolytic, but about a third of the strains showed some degree of green discoloration on blood agar plates. The inner core of this phenon was composed almost entirely of $H$. influenzae strains including representatives of the Pittman serotypes and Kilian biotypes I, II, IV and V. The strains received as $H$. aegyptius formed a tight subgroup at the $90 \%$ similarity level. Strain $\mathrm{H} 137$ clustered with this subgroup but its properties suggest that it has become mislabelled since the work of Sneath \& Johnson (1973). Phenon 1 also contained the type strains of $H$. haemoglobinophilus (H15) and $H$. paraphrohaemolyticus (H87). A group of eight atypical strains joined the phenon at a similarity of 80 to $85 \%$. When the pattern coefficient dendrogram was considered some strains appeared to be misplaced in the $S_{G}$ dendrogram. The type strain of $H$. segnis $(\mathrm{H} 117)$ became a satellite of phenon 8a but did not group well with any other cluster, so it was transferred to the ungrouped strains. Strains $\mathrm{H} 22$ ( $H$. haemolyticus) and H67 (H. parahaemolyticus) moved into phenons 3 and 4, respectively, and were transferred to those groups. A strain of $H$. influenzae (H57) moved from phenon 3 into phenon 1 on the pattern coefficient computation, and as it required both $\mathrm{X}$ and $\mathrm{V}$ it seemed better placed there.

Phenon 2 (the 'parasuis' cluster) contained strains which were from swine but required only $\mathrm{V}$ factor. Six strains received as $H$. suis had lost their $\mathrm{X}$ dependence (if they ever possessed it). One strain labelled $H$. parasuis (H122) moved to phenon 2 from the ungrouped strains in the pattern coefficient dendrogram, and was transferred to this phenon.

Phenon 3 (the 'parahaemolyticus' cluster) contained mainly haemolytic V-requiring strains, predominantly porcine in origin. All three serotypes were included. Duplicates of the Shope strain (H68 and H70) were $93 \%$ similar. Two strains of H. pleuropneumoniae (H118 and H119) were also in phenon 3. One strain of $H$. paraphrophilus (H86) appeared here and not with the other three strains in phenon 4: it differed from the latter in being oxidase positive, but this alone would not account for its position. Some non-haemolytic strains showed greening.

Phenon 4 (the 'mixed para' group) contained V-requiring strains from various sources. It contained seven strains labelled $H$. parainfluenzae (including the type strain H90), the holotype and two cotypes of $H$. paraphrophilus, and one strain of $H$. paraphrohaemolyticus (H89). There were strains of several other species in the phenon, and possibly some are mislabelled. In the pattern coefficient dendrogram H. segnis H116 (phenon 8 in Fig. 1) joined $H$. segnis $\mathrm{H} 115$, and therefore $\mathrm{H} 116$ was transferred to phenon 4. A few strains were haemolytic or showed greening on blood agar.

Phenon 5 (the 'parainfluenzae' cluster) contained four V-requiring strains of $H$. parainfluenzae and two $H$. gallinarum strains. The clustering in this area was not very satisfactory. Since strain H106 moved from the ungrouped strains into phenon 5 in the pattern coefficient dendrogram, it was transferred to phenon 5. It was, however, a duplicate of strain $\mathrm{H} 93$ which was in phenon 4 and remained there in the pattern coefficient dendrogram. It may be that phenons 4 and 5 are not distinct, because in the pattern coefficient dendrogram these two phenons were scarcely separated. Strains H91, H96 and H104 were all replicates of the same strain (the last received from a different source), and they were quite closely grouped in both $S_{G}$ and $S_{P}$ dendrograms (see Fig. 1).

Phenon 6 (the 'avium' cluster) consisted of four $H$. avium strains (including the type strain), three V-requiring $H$. gallinarum strains and three $H$. parasuis strains. The composition of the phenon was the same in the pattern coefficient dendrogram. No strains were haemolytic but several showed greening.

Phenon 7 (the 'Actinobacillus-Pasteurella' cluster), with phenons 10 and 11, represented strains of Pasteurella and Actinobacillus. The clustering in this region of the phenogram was poor, and further study of strains of these genera would probably show that these three phenons were more closely allied than is indicated by Fig. 1. Thus, H130 and H131 were 


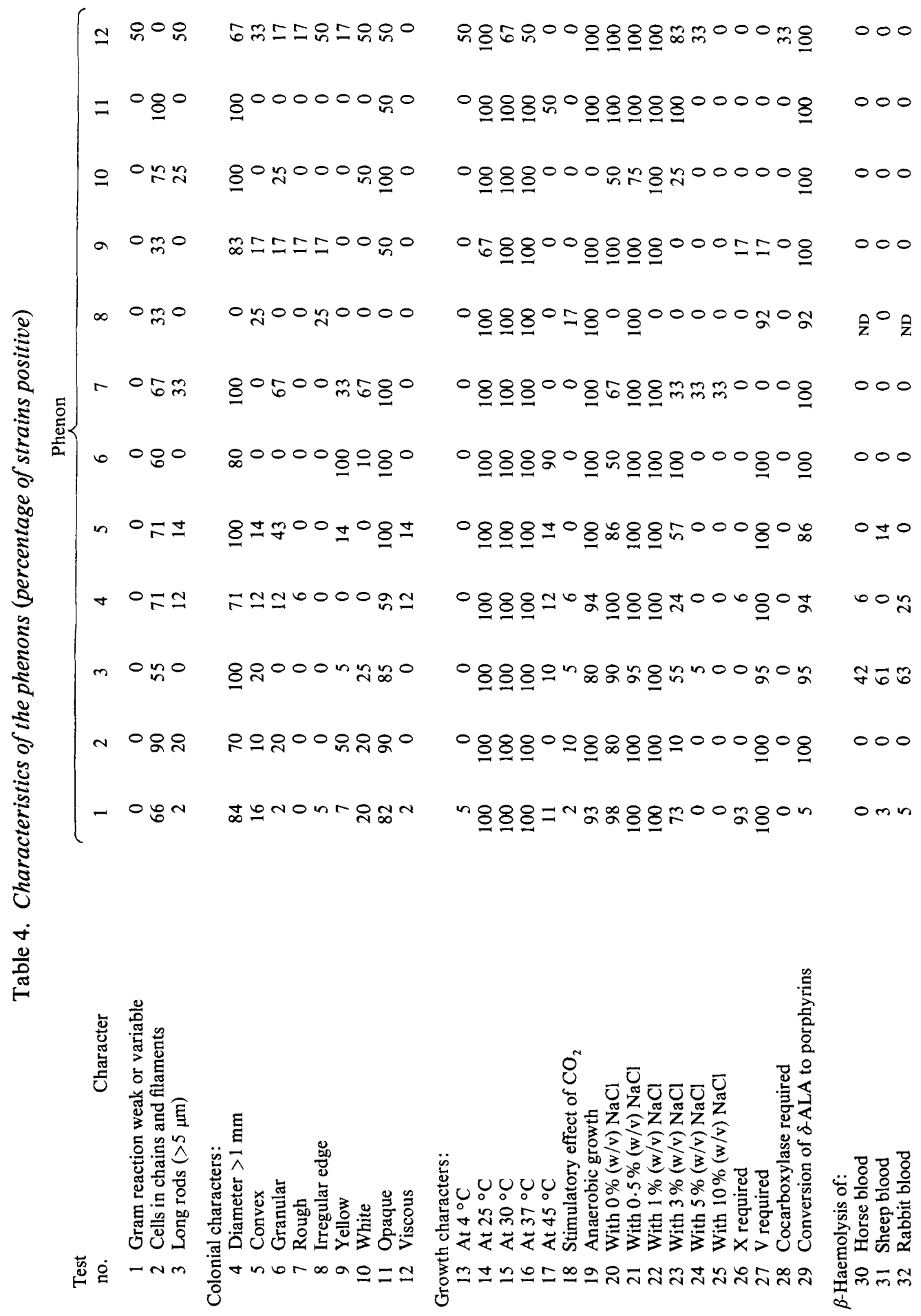




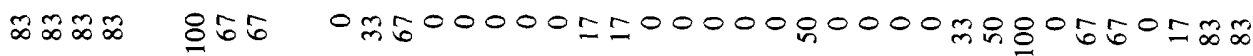

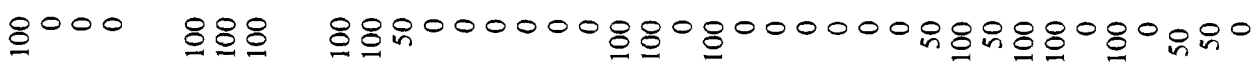

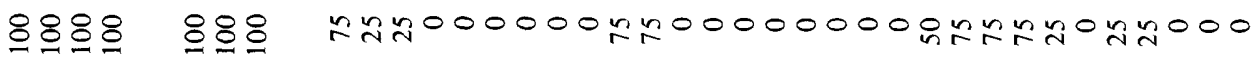

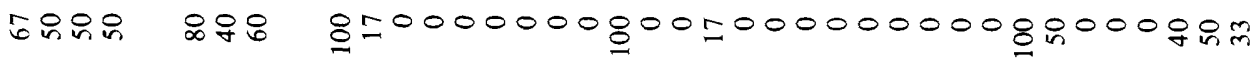
$m \infty \infty 0 \quad 800 \quad m 00000000 m=005000000808000 \infty=0 \infty$ 85mo 858 6080m00005500000000085800800m5

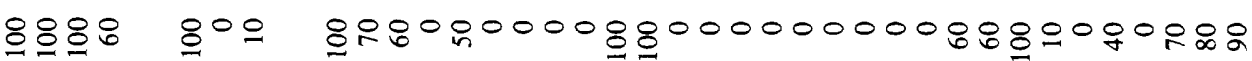

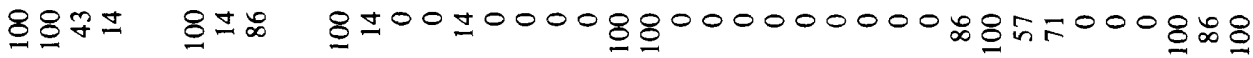

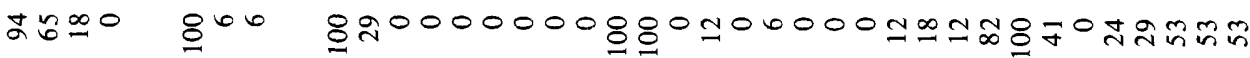

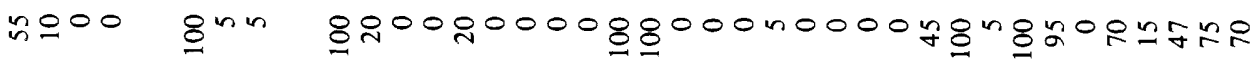

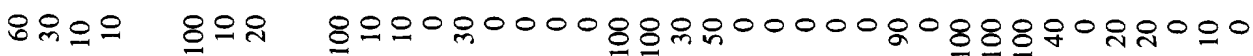

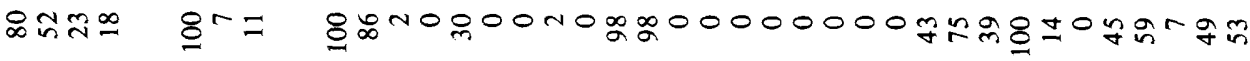

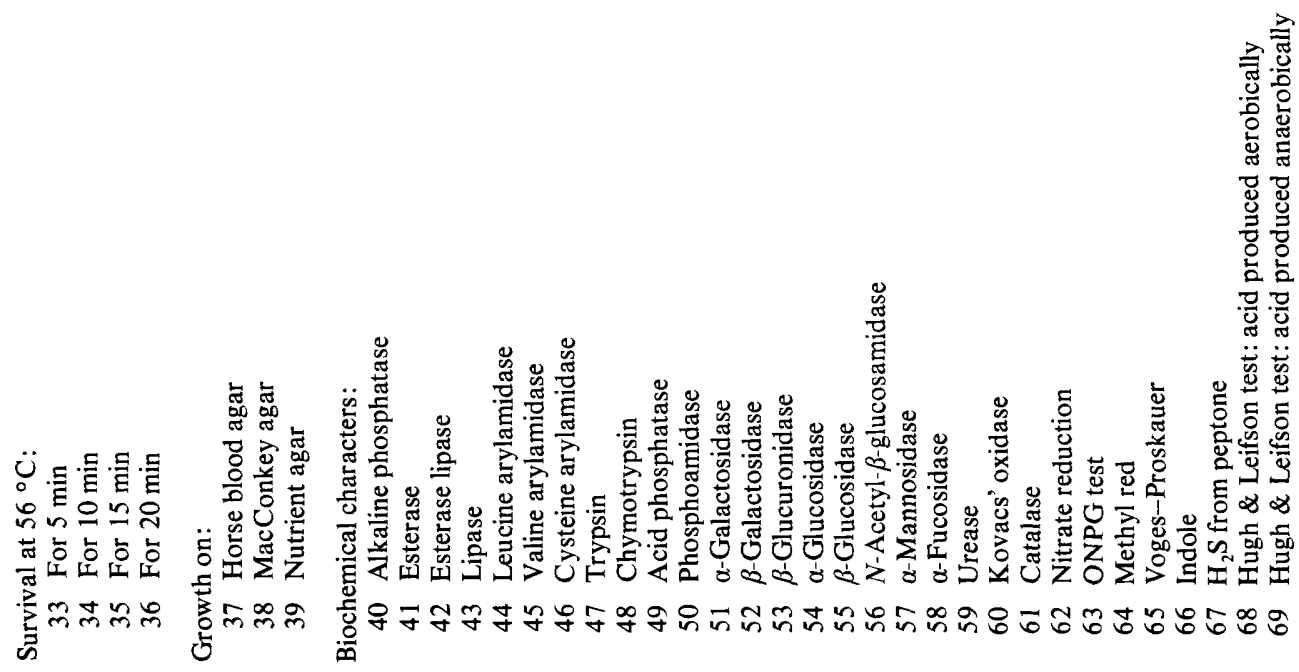



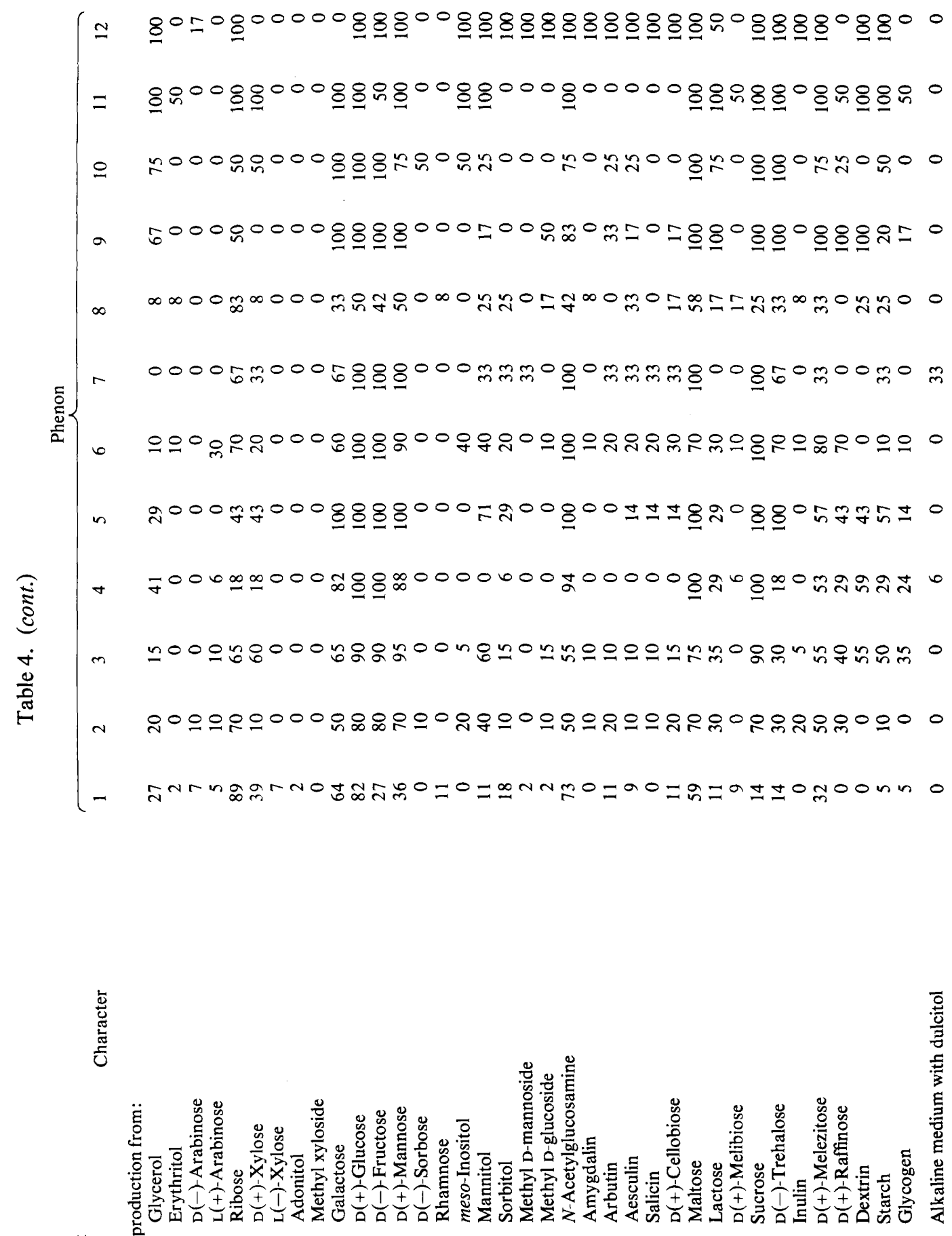

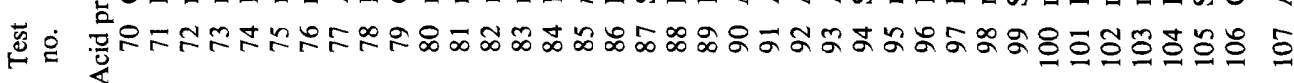




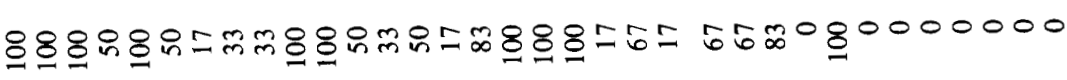

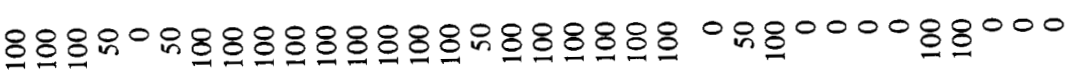

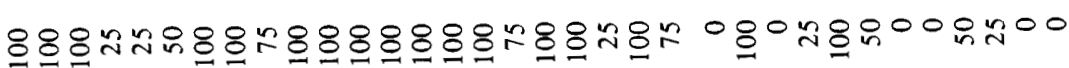

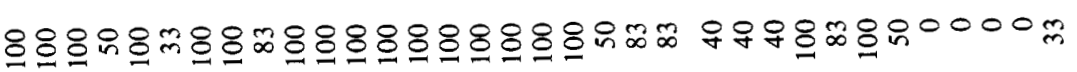

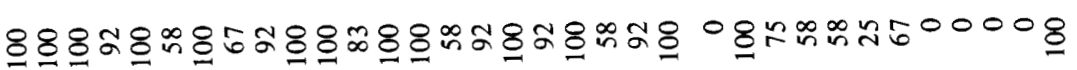

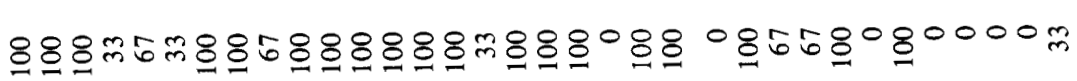

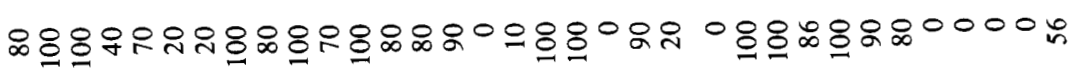

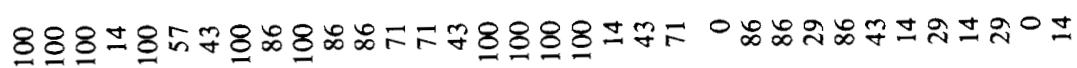

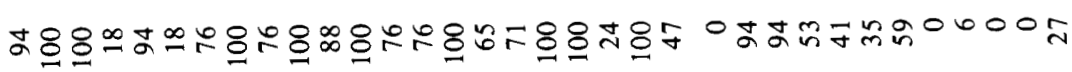

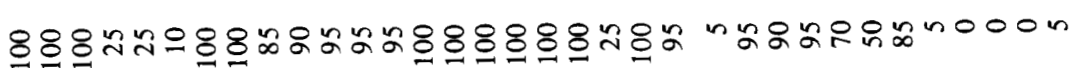

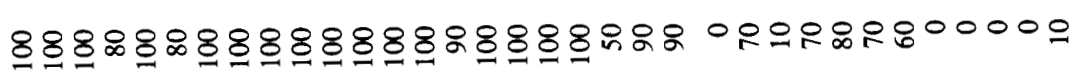

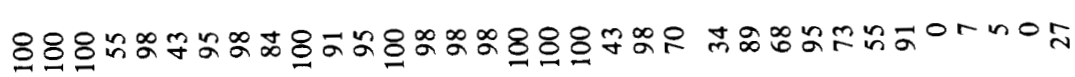

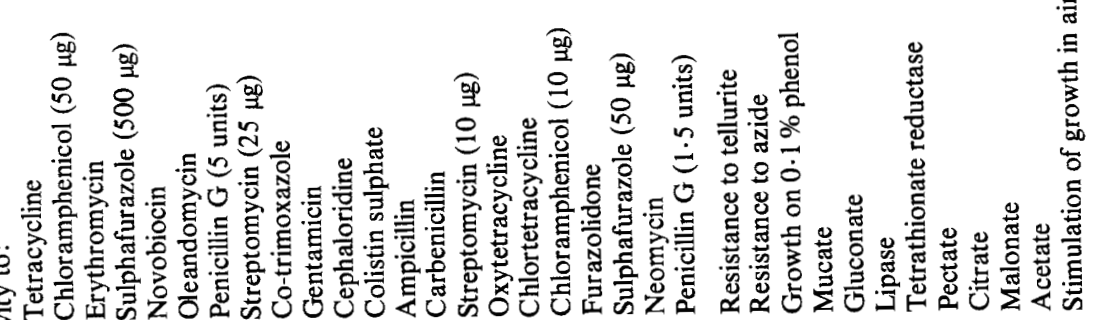

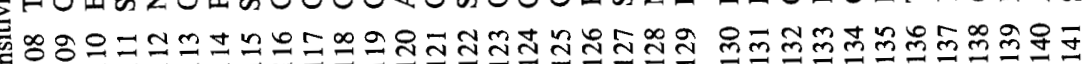


derived from the same strain, yet the former was in phenon 11 and the latter in phenon 7 . One strain, H133, seemed to be closest on the basis of the pattern coefficient to phenon 10 and was transferred to that group. Strain H148, received as H. influenzae-murium (Csukás, 1976), appeared more like a strain of Pasteurella than Haemophilus and did not require $\mathrm{X}$ or $\mathrm{V}$ factors. Moreover, it identified as P. multocida using the matrix of Bascomb et al. (1973).

Phenon 8 (the 'somnus' cluster) contained strains which required $\mathrm{V}$ alone. They were divided into two subgroups, corresponding to $H$. paragallinarum (8a) and $H$. somnus $(8 \mathrm{~b})$, together with one strain of $H$. segnis (H116). If more strains had been included these subclusters may have been well-separated species. The strains in phenon 8 were characterized by a requirement for a small concentration of $\mathrm{NaCl}$ for growth in air or in $5-10 \% \mathrm{CO}_{2}$ in air, grew slowly, and gave pinpoint colonies on chocolate agar at $37^{\circ} \mathrm{C}$ after $24 \mathrm{~h}$ incubation. In the pattern coefficient dendrogram the four strains of $H$. paragallinarum, though remaining a tight cluster, were a distant satellite group to phenon 1, and thus separated from the cluster of $H$. somnus strains (which remained together). Two strains of $H$. segnis became a satellite of phenons 3 and 4 . These differences are probably due to the slow growth of the strains of phenon 8. Ungrouped strains that were loosely associated with phenon 8 were $H$. vaginalis $\mathrm{H} 65$, a slow-growing strain of $H$. paragallinarum (H114), two strains of $H$. haemoglobinophilus ( $\mathrm{H} 18$ and $\mathrm{H} 20)$, and strains of H. haemolyticus $(\mathrm{H} 23)$ and $H$. influenzae (H54).

Phenon 9 (the 'aphrophilus' cluster) contained five strains of $H$. aphrophilus including the type strain $\mathrm{H}$ 9. None of these required $\mathrm{X}$ or $\mathrm{V}$ for growth. Also included in both the $S_{G}$ and $S_{P}$ phenograms was a strain ( $\left.\mathrm{H} 8\right)$ received as $H$. influenzae biotype III which appeared to require both $\mathrm{X}$ and $\mathrm{V}$, but was $\delta$-ALA positive. Most strains showed some greening, but none was haemolytic.

Phenon 10 (the 'Pasteurella' cluster) contained the three remaining Pasteurella strains. Two ungrouped strains attached to it were $H$. haemoglobinophilus $\mathrm{H} 17$ and $H$. parainfluenzae H106 which was moved to phenon 5 (see above).

Phenon 11 (the 'Actinobacillus' cluster) contained the remaining strains of Actinobacillus.

Between phenon 11 and phenon 12 there were 15 ungrouped strains received under various names (Fig. 1). Most of these remained in the ungrouped residue near the foot of the dendrogram derived from the pattern coefficient. They are considered further in the Discussion.

Phenon 12 (the 'piscium' cluster) contained all the strains from fish except for the carp strain $\mathrm{H} 158$, which was ungrouped. The two cocarboxylase-requiring strains of $H$. piscium (H159, H160) clustered separately from the four Weymouth fish isolates which did not require cocarboxylase. It is possible that if more strains had been available there would have been two distinct groups. Three strains appeared to be weakly Gram-positive or Gram-variable, a characteristic noted by Kilian (1976a).

\section{General features of the pattern coefficient dendrogram}

The differences between the $S_{G}$ and $S_{P}$ dendrograms as they relate to single strains have been mentioned above. The general features of the $S_{p}$ dendrogram (Fig. 3) merit brief mention. The phenons in Fig. 1 were substantially the same in the $S_{P}$ dendrogram, as would be expected from the rather uniform values for vigour in Table 3. Phenons 4 and 5 were partly intermingled and phenon 8 appeared as two separate groups, $H$. paragallinarum and $H$. somnus, as noted above. The relationships of the major groups in the two dendrograms were somewhat different: these probably have little significance (see Discussion).

\section{Characteristics of the phenons}

The characteristics of the 12 phenons are shown in Table 4 . It was not possible to find a set of tests that permitted unambiguous separation of all the phenons. The most discriminating tests in Table 4 are: test 9 , yellow pigment; 17 , growth at $45^{\circ} \mathrm{C} ; 22$, growth on $1 \% \mathrm{NaCl} ; 26$, 
requirement for $\mathrm{X} ; 27$, requirement for $\mathrm{V} ; 28$, requirement for cocarboxylase; 53, $\beta$-glucuronidase; $58, \alpha$-fucosidase; 60 , oxidase; 61 , catalase; 63 , ONPG; 86 , acid from mannitol; 97 , acid from lactose; 99 , acid from sucrose; 100 , acid from trehalose.

\section{DIS CUSSION}

The groupings are not as clear-cut as those often found in numerical taxonomic studies. A partial explanation may be the level of test reproducibility, though the value of $5 \%$ found in this study is not particularly high (Sneath, 1974; Jones, 1975; Wilkinson \& Jones, 1977; Goodfellow et al., 1979; Austin et al., 1979). A more likely reason is the fastidious growth requirements of the bacteria. Not all strains gave clear-cut acidity from glucose in Hugh \& Leifson or API 50E tests, possibly due to suboptimal growth. The influence of this on numerical taxonomy has not been explored, but one would expect that strains that were unable to manifest their full metabolic potential would commonly fall outside the tight clusters formed by strains that were growing under better conditions. Alternatively, the strains which appeared as satellite or ungrouped strains could have been misidentified so that the names under which they were received were erroneous. It is difficult to know which explanation is most likely; some comments on individual strains are noted below. The explanation is not simply due to differences in vigour, because results with the pattern coefficient affected only a minority of the poorly-clustered strains.

Although the nucleus of the phenon 1 cluster was composed of classical $H$. influenzae, its internal structure was not very clear. Kilian $(1976 a)$ divided $H$. influenzae into five biotypes on biochemical and morphological properties. In the present study these biotypes were not well separated but it should be noted that comparatively few strains from the different biotypes were included. There is some evidence that the biotypes are not entirely arbitrary groupings, e.g. Kilian et al. (1979) found that $93 \%$ of strains causing meningitis belonged to biotype I, whereas this biotype is uncommon in the respiratory tract. Our findings do not provide much evidence on the relationships of the capsular serotypes, but Kilian et al. (1979) noted that there may be a clinically significant correlation between biotype and serotype. Strain H128 was a satellite to the main core of $H$. influenzae, in a similar position to that found in the study of Sneath \& Johnson (1973).

Haemophilus aegyptius has been differentiated from $H$. influenzae on the basis of its haemagglutinating ability, but this feature is not particularly characteristic of strains causing acute conjunctivitis (Smith, 1954; Kilian et al., 1976). We examined a few strains, using human blood by the method of Davis et al. (1950). Our findings were similar to Kilian's in that some strains of several phenons, but not all conjunctival strains, were positive. The strains in the small subcluster (also observed by Sneath \& Johnson, 1973) which were received under the name $H$. aegyptius tended to ferment fewer carbohydrates than typical strains of $H$. influenzae. Kilian (1976a) found that $H$. aegyptius strains belonged mainly to his biotype III, but several strains of that biotype are found elsewhere in Fig. 1.

Haemophilus haemolyticus was originally separated from $H$. influenzae because it was haemolytic. Kilian (1976a) considered it to be a separate species, but the present study suggests they are haemolytic variants. In the study of Sneath \& Johnson (1973) strain H21 was found to require X and V for growth, but in Kilian's work $(1976 a)$ and the present study, it required $\mathrm{V}$ only for growth and gave a pink fluorescence in the $\delta$-ALA test typical of $\mathrm{X}$-independence. However, the peculiarities of haemolysis noted in this study and in that of Sneath \& Johnson (1973) point to the fact that it is not just a contaminated culture; the strain gave weak $\beta$-haemolysis close to the colony and greenish discoloration of the blood around the $\beta$-haemolytic zone. White \& Granick (1963) showed certain strains had enzymic activities typical of $\mathrm{X}$-independent strains but were unable to grow on media totally devoid of haematin. Kilian (1976a) suggested this was the explanation for the growth requirements determined by Sneath \& Johnson (1973). 
Four of the six strains of $H$. haemoglobinophilus $(\mathrm{H} 16, \mathrm{H} 17, \mathrm{H} 18, \mathrm{H} 20)$ required only $\mathrm{X}$ for growth as expected, but they, with $\mathrm{H} 19$, were all among the ungrouped strains and did not cluster together. Strain $\mathrm{H} 19$ required no growth factors; it may be an X-independent mutant. The type strain $\mathrm{H} 15$ in this study appeared to require both $\mathrm{X}$ and $\mathrm{V}$, in contrast to the findings of Sneath \& Johnson (1973), but was in phenon 1 in both studies. It may be that several species of Haemophilus occur in dogs, and these organisms certainly need further study.

The three strains of $H$. paraphrohaemolyticus all required only $\mathrm{V}$, but two of them (including the type strain H87) have lost their haemolytic ability and appeared as peripheral members of phenon 1 . The third (H89) occurred in phenon 4, which would seem to be a more likely position for strains of this species. Nevertheless, the strains in phenon 1 (Fig. 1) were still members of that cluster in the $S_{P}$ dendrogram. This species likewise deserves further investigation. These strains had adapted to growth in air without $\mathrm{CO}_{2}$.

Kilian (1976a) proposed a new species $H$. segnis with a GC value of $43-44$ mol\%, which is rather high for the genus. The status of this species is not clear. The type strain H117 was in phenon 1 (but was ungrouped in the $S_{p}$ dendrogram) whereas the other strains were in phenon 4 or phenon 8 (Fig. 1). All required only V factor, and gave results in reasonable accord with those of Kilian \& Theilade (1978).

Phenon 2 consisted of one of the groups of porcine strains (others were in phenon 6), but though the species $H$. suis was described as requiring $X$ and V (Lewis \& Shope, 1931), the surviving cotype H59 (if it is authentic) requires only V (Sneath \& Johnson, 1973; Kilian, 1976 a). It is now the type strain of $H$. parasuis in the Approved Lists (Skerman et al., 1980). Swine strains requiring both $\mathrm{X}$ and $\mathrm{V}$ have, however, been isolated recently (Biberstein et al., 1977). The organism associated with enteritis of rabbits (Targowski \& Targowski, 1979) resembles strains of phenon 2 in many ways.

Phenons 3, 4 and 5 were composed of V-requiring strains from the respiratory tracts of various animals. Perhaps the three clusters should be combined, but there are indications that they may be best considered as separate groups. Phenon 3 represented strains that are usually haemolytic and urease positive, which are considered by Biberstein et al. (1977) to represent $H$. parahaemolyticus. However, the identity of this species, in view of the discrepant position of what are thought to be different stocks of the type strain (H21, H149) is dubious. Some are from swine (including those labelled $H$. pleuropneumoniae, which do not seem to be distinct from the others): unfortunately the type strain of $H$. pleuropneumoniae was not studied.

Phenons 4 and 5 were partly intermingled in the pattern coefficient phenogram, which shows their close relationship. Most strains of phenon 4 correspond to $H$. parainfluenzae; $H$. paraphrophilus does not seem to be distinct from them, so this may represent variants that require $\mathrm{CO}_{2}$. Strain $\mathrm{H} 24$ is a haemolytic strain with unusual growth requirements. It needed both $\mathrm{X}$ and $\mathrm{V}$ for growth but was able to convert $\delta$-aminolaevulinic acid to porphyrin. It may perhaps lack the enzyme needed to chelate iron into the porphyrin.

Apart from three swine strains, phenon 6 represented $H$. avium strains; these differ from $H$. paragallinarum in not producing coryza in chickens (Hinz \& Kunjara, 1977). Whether strains $\mathrm{H} 109$ and $\mathrm{H} 111$, received as $H$. gallinarum, produce coryza is not known, but they seem likely to be strains of $H$. avium. This phenon is taxon C of Kilian (1976a).

It is not clear why phenons 7, 10 and 11 (Actinobacillus and Pasteurella) did not form one cluster as in the study of Sneath \& Johnson (1973), but the present findings do emphasize the relatedness of these two genera to Haemophilus.

As noted earlier, phenon 8 may well represent two species, $H$. somnus and $H$. paragallinarum. The results for $H$. somnus are in good agreement with those of Bailie $e t$ al. (1973); this species, though not validly published, is associated with a characteristic disease of cattle (thromboencephalomyelitis) and its phenotypic peculiarities suggest it is a good taxon. The four strains of $H$. paragallinarum (including the type strain H144) produce coryza in 
fowls (Hinz \& Kunjara, 1977) and again this, with the phenotypic properties of phenon 8 , suggests it is also a good taxon.

The satellite strain $\mathrm{H} 54$ was a member of biotype $\mathrm{V}$ of $\mathrm{H}$. influenzae in the classification of Kilian $(1976 a)$. It required both $\mathrm{X}$ and $\mathrm{V}$ and was $\delta$-ALA negative, and we are unable to explain its position as an ungrouped strain in both the $S_{G}$ and $S_{P}$ phenograms.

The growth requirements of the strains of $H$. aphrophilus in phenon 9 require comment. There are conflicting reports on the X-requirement of this species (Khairat, 1940; Sutter \& Finegold, 1970; Sneath \& Johnson, 1973). Kilian (1976a) found it was able to convert $\delta$-aminolaevulinic acid to porphyrin, as we found in the present study. It is possible that $H$. aphrophilus readily mutates to X-independence (Boyce et al., 1969), or these strains may lack the power to readily chelate iron into the porphyrin. Haemophilus aphrophilus also adapts readily to growth in air without added $\mathrm{CO}_{2}$ (Khairat, 1940). We did not find strain $\mathrm{H} 10$ was particularly different from $\mathrm{H} 9$ as implied by the report of the Subcommittee on the Taxonomy of Haemophilus (Biberstein \& Zinnemann, 1971).

All the strains from fish were found in phenon 12 except for that from carp erythrodermatitis (H158). If phenon 12 is considered to be one species, $H$. piscium, then a requirement for cocarboxylase is not a constant feature. The low similarity $(65 \%)$ with other species of Haemophilus suggests that it may be best excluded from the genus, but where it should go is not clear.

The ungrouped strains between phenons 11 and 12 were received under a variety of names. Only H16, H122 and $\mathrm{H} 129$ required X, V or both. Several showed haemolysis or greening. The pattern coefficient computation suggested that $\mathrm{H} 122$ might be an aberrant strain of phenon 2, which would be in accord with its V-requirement and porcine origin. Strain H16 was X-requiring and $\delta$-ALA negative, as found by Sneath \& Johnson (1973), but did not group (in either phenogram) with $\mathrm{H} 15$ as in that study. Strain H129 appears to be an aberrant member of Haemophilus and may possibly represent a new species of this genus. We found it was $\delta$-ALA negative, but required V as well as X. Kilian (1976a) found it needed X only, and Ryan (1968) believed it did not require $V$, though he noted slight satellitism around V-producing staphylococci. We found, unlike Ryan (1968), that nitrate was reduced; other properties were in good agreement.

The present groupings agree quite closely with those obtained by Sneath \& Johnson (1973) where strains were common to the two studies. Thus, the core of strains of $H$. influenzae in phenon 1 and the peripheral position in that phenon of $\mathrm{H} 1, \mathrm{H} 15, \mathrm{H} 21, \mathrm{H} 34$ and $\mathrm{H} 128$ are evident in both surveys. Similarly, strains H109, H110, H111 and H125 form a tight cluster in both. The studies differ in the greater diversity in the V-requiring strains; the small number of strains in the earlier study may account for much of this variation. The principal difference in broad groupings is the scatter amongst strains of Actinobacillus and Pasteurella in the present investigation.

This study also agrees reasonably well with that of Kilian (1976a). Many of the phenons correspond to groups recognized by Kilian: phenon 1 is $H$. influenzae, 2 is $H$. parasuis, 3 is mainly $H$. parahaemolyticus, 5 is probably $H$. parainfluenzae biotype I, 6 is taxon $\mathrm{C}, 8 \mathrm{a}$ is possibly $H$. paragallinarum, 9 is $H$. aphrophilus and 12 is $H$. piscium. However, we did not find clear groupings that correspond to $H$. haemolyticus, $H$. segnis or $H$. paraphrophilus. The disagreements on individual tests were rather few when the different test methods are taken into account. Our tests for catalase, oxidase, and carbohydrate fermentations were evidently rather insensitive; these tests account for many of the discrepancies. We did, however, obtain the opposite result from Kilian in some instances that seemed unlikely to be due to these factors or the sets of strains: thus phenon 2 was oxidase positive; phenon 6 was $\alpha$-glucosidase negative; phenon 12 produced acid from mannitol and reduced nitrate.

The relation of the phenons to serology is difficult to assess, as the data are fragmentary. The relative serological homogeneity of $H$. influenzae has long been known (Pittman, 1931), and Nicolet (1971) has shown similar homogeneity in $H$. parahaemolyticus; in both cases 
serological subgroups have been recognized which are concordant with the clusters found here. The grouping of most strains of $H$. paraphrophilus in phenon 4 is congruent with its serological homogeneity (Frazer et al., 1975) and the heterogeneity of $H$. paraphrohaemolyticus is reflected in the scattered occurrence of the strains in Fig. 1. Too few strains of $H$. aphrophilus and $H$. haemoglobinophilus were studied for comparison with the serological data of Frazer et al. (1975). The grouping of $H$. somnus strains agrees with the serological homogeneity reported by Shigidi \& Hoerlein (1970).

The present findings emphasize that host animal is an inadequate basis on which to establish species of Haemophilus. One animal can carry several different species, and it seems likely that strains of one phenon can sometimes be found in several animals. Growth factor requirement is also an insecure basis for speciation, particularly in the strains that require only V. Similarly, little emphasis should be placed on haemolysis or $\mathrm{CO}_{2}$ requirement. However, a few phenons are linked to a characteristic disease (see Nicolet, 1968, 1971; Kilian, 1976a, b, for discussion).

A matter of considerable practical importance is the extent to which the groups within the genus Haemophilus can be distinguished. The pattern of variation in our results is not so clear-cut as is seen in some bacterial genera, and it has not been possible to find a small set of highly discriminatory tests. There are two ways in which this aspect can be explored - by estimating the overlap between the phenons statistically (Sneath, 1980), and by using the phenon descriptions as a data base against which to identify new isolates by numerical methods such as those of Bascomb et al. (1973). It is hoped to carry out further work on these lines in the near future.

Although little is known in detail about the patterns of taxonomic variation in different groups of bacteria, there is some evidence that the variation in parasitic groups is much more complex than in predominantly free-living forms (e.g. Streptococcus, phytopathogenic pseudomonads: Jones, 1978; Palleroni, 1975). It should also be remembered that some of the apparent misplacements of individual strains may be due to the occurrence of hybrids, of unusual plasmids and the like. Plasmids are reported as common in $H$. influenzae (Stuy, 1979), though the extent to which they affect the phenetic position of bacteria is still poorly known. Alternatively, some apparently aberrant strains (e.g. H54, H129) may be the nuclei of hitherto unrecognized new species.

We acknowledge the assistance of M. J. Sackin on computing, and we thank the Science Research Council for support to one of us (A. K. B.) for a Postgraduate Award and the Medical Research Council for a Programme Grant. We are also very grateful to all those who provided strains for study.

\section{REFERENCES}

Austin, B., Garges, S., Conrad, B., Harding. E. E., Colwell, R. R., Simudu, U. \& TAGA, N. (1979). Comparative study of the aerobic, heterotrophic bacterial flora of Chesapeake Bay and Tokyo Bay. Applied and Environmental Microbiology 37, 704714.

BaILIE, W. E. (1969). Characterization of Haemophilus somnus (new species), a microorganism isolated from infectious thromboembolic meningoencephalomyelitis of cattle. DVM dissertation, Kansas State University, U.S.A.

Bailie, W. E., Coles, E. H. \& Weide. K. D. (1973). Deoxyribonucleic acid characterization of a microorganism isolated from infectious thromboembolic meningoencephalomyelitis of cattle. International Journal of Systematic Bacteriology 23, 231-237.

Bascomb, S., Lapage, S. P., Curtis. M. A. \& WillcoX, W. R. (1973). Identification of bacteria by computer: identification of reference strains. Journal of General Microbiology 77, 291-315.

Bergey, D. C., Harrison, F. C., Breed, R. S., HAMmer, B. W. \& Huntoon, F. M. (1923). Bergey's Manual of Determinative Bacteriology. 1st edn. Baltimore: Williams \& Wilkins.

Biberstein, E. L. \& White, D. C. (1969). A proposal for the establishment of two new Haemophilus species. Journal of Medical Microbiology 2, 75-78.

Biberstein. E. L. \& Zinnemann, K. (1971). Report (1966-1970) of the Subcommittee on the Taxonomy of Haemophilus to the International Committee on Nomenclature of Bacteria. International Journal of Systematic Bacteriology 21, 133-134.

Biberstein, E. L., Gunnarsson, A. \& Hurvell, B. (1977). Cultural and biochemical criteria for the identification of Haemophilus spp. from swine. American Journal of Veterinary Research 38, 7-11. 
DE BLIECK, L. (1931). Een haemoglobinophile bacterie als oor zaak van coryza-infectiosa gallinarum. Tijdschrift voor diergeneeskunde 58, 310-314.

Boyce, J. M. H., Frazer, J. \& ZinnemanN, K. (1969). The growth requirements of Haemophilus aphrophilus. Journal of Medical Microbiology 2 , 55-62.

Buchanan, R. E., Holt, J. G. \& Lessel, E. F., Jr (1966). Index Bergeyana. Baltimore: Williams \& Wilkins.

Cowan, S. T. (1974). Cowan \& Steel's Manual for the Identification of Medical Bacteria, 2nd edn. Cambridge: Cambridge University Press.

Craigie, J. (1931). Studies on the serological reactions of the flagella of B. typhosus. Journal of Immunology 21, 417-511.

Cruikshank, R., Duguid, J. P., Marmion, B. P. \& SwaIn, R. H. H. (1975). Practice of Medical Microbiology, vol. 2, 12th edn, p. 35. Edinburgh: Livingstone.

CSUKẢs, Z. (1976). Re-isolation and characterization of Haemophilus influenzae-murium. Acta microbiologica Academiae scientiarum hungaricae 23, 89-96.

Davis, D. J., Pittman, M. \& Griffiths, J. J. (1950). Hemagglutination by the Koch-Weeks bacillus (Haemophilus aegyptius). Journal of Bacteriology 59, 427-431.

Delaplane, J. P., Erwin, L. E. \& Stuart, H. O. (1934). A hemophilic Bacillus as the cause of an infectious rhinitis (coryza) of fowls. Rhode Island State College Agricultural Experiment Station Bulletin 244, 1-12.

Diernhofer, K. (1949). Haemophile Bakterien im Geschlechtstrakt des Rindes. Wiener tierärtzliche Monatsschrift 36, 582-588.

Feltham, R. K. A., Power, A. K., Pell, P. A. \& SNEATH, P. H. A. (1978). A simple method for storage of bacteria at $-76^{\circ} \mathrm{C}$. Journal of Applied Bacteriology 44, 313-316.

Fildes, P. (1921). The nature of the effect of blood-pigment upon the growth of $B$. influenzae. British Journal of Experimental Pathology 2, 16-25.

Frazer, J., ZINNemanN, K. \& Boyce, J. M. H. (1975). The agglutination reactions of Haemophilus paraphrophilus and $H$. paraphrohaemolyticus, and some observations on the agglutination of $H$. aphrophilus and $H$. haemoglobinophilus (H. canis). Journal of Medical Microbiology 8, 89-96.

Frazier, W. C. (1926). A method for the detection of changes in gelatin due to bacteria. Journal of Infectious Diseases 39, 302-309.

Gardner, H. L. \& Dukes, C. D. (1955). Haemophilus vaginalis vaginitis. American Journal of Obstetrics and Gynecology 69, 962-976.

Goodfellow, M., Alderson, G. \& Lacey, J. (1979). Numerical taxonomy of Actinomadura and related actinomycetes. Journal of General Microbiology 112 , 95-111.

Gordon, R. E. \& SMith, M. M. (1955). Rapidly growing acid fast bacteria. II. Species description of Mycobacterium fortuitum Cruz. Journal of Bacteriology 69, 502-507.

Hauduroy, P., Ehringer, G., Urbain, A., Guillot, G. \& Magrou, J. (1937). Dictionnaire des Bactéries Pathogènes. Paris: Masson et Cie.
Hinz, K. H. \& KunJara, C. (1977). Haemophilus avium, a new species from chickens. International Journal of Systematic Bacteriology 27, 324-329.

Hugh, R. \& LeIFson, E. (1953). The taxonomic significance of fermentative versus oxidative metabolism of carbohydrates by various Gram-negative bacteria. Journal of Bacteriology 66, 24-26.

Ivanovics, G. \& Ivanovics, C. H. (1937). Beiträge zur Kenntnis des "Bacterium influenzae-murium" (Kairies \& Schwartzer). Zentralblatt für Bakteriologie, Hygiene und Infektionskrankheit (Abteilung I, Originale) 139, 184-188.

Johnson, R. (1972). Aspects of the taxonomy of Bordetella and related organisms. Ph.D. thesis, Leicester University, U.K.

Johnson, R. \& Sneath, P. H. A. (1973). Taxonomy of Bordetella and related organisms of the families Achromobacteraceae, Brucellaceae and Neisseriaceae. International Journal of Systematic Bacteriology 23, 381-404.

JONES, D. (1975). A numerical taxonomic study of coryneform and related bacteria. Journal of General Microbiology 87, 52-96.

JONES, D. (1978). Composition and differentiation of the genus Streptococcus. In Streptococci, pp. 1-49. Edited by F. A. Skinner \& L. B. Quesnel. London: Academic Press.

KaIries, A. \& Schwartzer, K. (1936). Studien zu einer bakteriellen Influenza der Mäuse und Beschreibung eines Bacterium influenzae murium. Zentralblatt für Bakteriologie, Hygiene und Infektionskrankheit (Abteilung I, Originale) 137, 351-359.

Kawai, Y. \& Yabuuchi, E. (1975). Pseudomonas pertucinogena sp. nov., an organism previously misidentified as Bordetella pertussis. International Journal of Systematic Bacteriology 25, 317-323.

Kennedy, P. C., Frazier, L. M., Theilen, G. H. \& Biberstein, E. L. (1958). A septicemic disease of lambs caused by Hemophilus agni (new species). American Journal of Veterinary Research 19 , 645-654.

KhaIRAT, O. (1940). Endocarditis due to a new species of Haemophilus. Journal of Pathology and Bacteriology 50, 497-505.

KILIAN, M. (1974). A rapid method for the differentiation of Haemophilus strains: the porphyrin test. Acta pathologica et microbiologica scandinavica $\mathbf{B 8 2}, 835-842$.

Kilian, M. (1976a). A taxonomic study of the genus Haemophilus, with a proposal of a new species. Journal of General Microbiology 93, 9-62.

KILIAN, M. $(1976 b)$. The haemolytic activity of Haemophilus species. Acta pathologica et microbiologica scandinavica B84, 339-341.

Kilian, M. (1977). Announcement of the valid publication of new names and new combinations previously effectively published outside the IJSB. International Journal of Systematic Bacteriology 27, 306.

Kilian, M. \& Theilade, J. (1978). Amended description of $H$. segnis Kilian 1977. International Journal of Systematic Bacteriology 28, 411-415.

Kilian, M., Mordhorst, C.-H., Dawson, C. R. \& LAUTROP, H. (1976). The taxonomy of haemophili 
isolated from conjunctivae. Acta pathologica et microbiologica scandinavica B84, 132-138.

Kilian. M.. Nicolet, J. \& Biberstein, E. L. (1978). Biochemical and serological characterization of $H$. pleuropneumoniae (Matthews and Pattison, 1961) Shope 1964 and proposal of a neotype strain. International Journal of Systematic Bacteriology 28. $20-26$.

Kil.ian. M.. Sørensen, I. \& Frederiksen, W. (1979). Biochemical characteristics of 130 recent isolates from Haemophilus influenzae meningitis. Journal of Clinical Microbiology 9, 409-412.

King. E. A. \& Tatum, H. W. (1962). Actinobacillus actinomycetemcomitans and Haemophilus aphrophilus. Journal of Infectious Diseases 111, 85-94.

Kovacs. N. (1956). Identification of Pseudomonas pyocianea by the oxidase reaction. Nature, London 178. 703 .

LehmanN, K. B. \& Neumann, R. O. (1896). Atlas und Grundriss der Bakteriologie und Lehrbuch der speziellen bacteriologischen Diagnostik, 1st edn. München: Lehmann.

LehmanN. K. B. \& Neumann, R. O. (1907). Atlas und Grundriss der Bakteriologie und Lehrbuch der speziellen bacteriologischen Diagnostik, 4th edn. München: Lehmann.

Lewis, P. A. \& SHOPE, R. E. (1931). Swine influenza II. A hemophilic bacillus from the respiratory tract of infected swine. Journal of Experimental Medicine 54. 361-371.

LwOFF, A. (1939). Revision et démembrement des Hemophilae. Le genre Moraxella nov. gen. Annales de l'Institut Pasteur 62, 168-176.

McGaughey, C. A. (1933). Organisms of the $B$. influenzae group in fowls. Journal of Comparative Pathology and Therapeutics 45, 58-66.

Mitchell, C. A. (1925). Hemophilus ovis (nov. spec.) as the cause of a specific disease of sheep. Journal of the American Veterinary Medical Association 68, $8-18$.

Murray, E. G. D. (1939). Family VIII. Parvobacteriaceae Rahn. In Bergey's Manual of Determinative Bacteriology, 5th edn, pp. 289-310. Edited by D. H. Bergey, R. S. Breed, E. G. D. Murray \& A. P. Hitchens. Baltimore: Williams \& Wilkins.

Nelson, J. B. (1933). Studies on an uncomplicated coryza of the domestic fowl. I. The isolation of a bacillus which produces a nasal discharge. Journal of Experimental Medicine 58, 289-295.

Neveu-Lemaire, M. (1921). Précis de Parasitologie Humaine, 5th edn. Paris: J. Lemaire.

Nicolet, J. (1968). Sur l'hémophilose du porc. I. Identification d'un agent fréquent: Haemophilus parahaemolvticus. Pathologia et microbiologia $\mathbf{3 1}$, 215-225.

Nicolet. J. (1971). Sur l'hémophilose du porc. Zentralblatt für Bakteriologie, Immunologie und Infektionskrankheit (Abteilung I, Originale) 216, $487-495$.

PAlleroni. N. J. (1975). General properties and taxonomy of the genus Pseudomonas. In Genetics and Biochemistry of Pseudomonas, pp. 1-36. Edited by P. H. Clarke \& M. H. Richmond. London: Wiley.

Pittman, M. (1931). Variation and type specificity in the bacterial species Haemophilus influenzae. Journal of Experimental Medicine 53, 471-492.

Pittman, M. (1953). Classification of the hemolytic bacteria of the genus Haemophilus: Haemophilus haemolyticus Bergey et al. and Haemophilus parahaemolyticus nov. spec. Journal of Bacteriology $\mathbf{6 5}$, 750-751.

Pittman, M. \& Davis, D. J. (1950). Identification of the Koch-Weeks bacillus (Haemophilus aegyptius). Journal of Bacteriology 59, 413-426.

Power, A. K. (1978). A taxonomic study of the genus Haemophilus. Ph.D thesis, Leicester University, U.K.

Rivers, T. M. (1922). Influenza-like bacilli. Growth of influenza-like bacilli on media containing only an autoclave-labile substance as an accessory food factor. Johns Hopkins Hospital Bulletin 33, 429431.

RyAN, W. J. (1968). An X-factor-requiring Haemophilus species. Journal of General Microbiology $\mathbf{5 2}$, 275-286.

Shigidi, M. A. \& Hoerlein, A. B. (1970). Characterization of the Haemophilus-like organisms of infectious thromboembolic meningoencephalitis of cattle. American Journal of Veterinary Research 31, 1017-1022.

SHope, R. E. (1964). Porcine contagious pleuropneumonia. I. Experimental transmission, etiology and pathology. Journal of Experimental Medicine $119,357-368$.

Skerman, V. B. D., McGowan, V. \& Sneath, P. H. A. (editors) (1980). Approved Lists of Bacterial Names. International Journal of Systematic Bacteriology 30, 225-420.

SмIтH, C. H. (1954). Relationships between haemagglutination and pathogenicity in strains isolated from eyes. Journal of Pathology and Bacteriology 18, 284-287.

Smith, P. B., Hancock, G. A. \& Rhoden, D. L. (1969). Improved media for detecting deoxyribonuclease producing bacteria. Applied Microbiology 18, 991-993.

SNeATH, P. H. A. (1956). Cultural and biochemical characteristics of the genus Chromobacterium. Journal of General Microbiology 15, 70-98.

SNeATH, P. H. A. (1966). Identification methods applied to Chromobacterium. In Identification Methods for Microbiologists, pp. 15-20. Edited by B. M. Gibbs \& F. A. Skinner. London: Academic Press.

SNEATH, P. H. A. (1974). Test reproducibility in relation to identification. International Journal of Systematic Bacteriology 29, 508-523.

SNEATH, P. H. A. (1980). BASIC program for determining overlap between groups in an identification matrix of percent positive characters. Computers and Geosciences 6, 267-278.

SNEATH, P. H. A. \& Johnson, R. (1972). The influence on numerical taxonomic similarities of errors in microbiological tests. Journal of General Microbiology 72, 377-392.

SNEATH, P. H. A. \& Johnson, R. (1973). Numerical taxonomy of Haemophilus and related bacteria. International Journal of Systematic Bacteriology 23, 405-418.

Sneath, P. H. A. \& Skerman, V. B. D. (1966). A list 
of type and reference strains. International Journal of Systematic Bacteriology 16, 1-133.

SNEATH, P. H. A. \& Sokal, R. R. (1973). Numerical Taxonomy: The Principles and Practice of Numerical Classification. San Francisco: W. H. Freeman.

SNieszko, S. F., Griffin, P. J. \& Friddle, S. B. (1950). A new bacterium (Haemophilus piscium n. sp.) from ulcer diseases of trout. Journal of Bacteriology 59, 699-710.

Stevens, M. (1969). Development and use of multiinoculation test methods for a taxonomic study. Journal of Medical Laboratory Technology 26, 253-263.

Stuy, J. H. (1979). Plasmid transfer in Haemophilus influenzae. Journal of Bacteriology 139, 520-529.

SutTER, V. \& Finegold, L. (1970). Haemophilus aphrophilus infections: clinical and bacteriologic studies. Annals of the New York Academy of Sciences 174, 468-487.

TARGowskI, S. \& TARGOWSKI, H. (1979). Characterization of a Haemophilus paracuniculus isolated from gastrointestinal tracts of rabbits with mucoid enteritis. Journal of Clinical Microbiology 9, 33-37.

ThJotTA, T. \& Avery, O. T. (1921). Studies on bacterial nutrition. II. Growth accessory substances in the cultivation of hemophilic bacilli. Journal of Experimental Medicine 34, 97-114.

Trevisan, V. (1889). I Generi e le Specie delle Batteriaceae. Milan: Zanaboni \& Gabuzzi.

White, D. C. \& Granick, S. (1963). Hemin biosynthesis in Haemophilus. Journal of Bacteriology 85, 842-850.

Wilkinson, B. J. \& Jones, D. (1977). A numerical taxonomic survey of Listeria and related bacteria. Journal of General Microbiology 98, 399-421.

Wilson, G. S. \& Miles, A. A. (1964). Topley \& Wilson's Principles of Bacteriology and Immunity, vol. 1, 5th edn. London: Arnold.

Winslow, C. E. A., Broadhurst, J., Buchanan, R. E., KRumwiede, C., Jr, Rogers, L. A. \& SMith, G. H. (1917). The families and genera of the bacteria. Journal of Bacteriology 2, 505-566.

Zinnemann, K., Rogers, K. B., Frazer, J. \& Boyce, J. M. H. (1968). A new V-dependent Haemophilus species preferring increased $\mathrm{CO}_{2}$ tension for growth and named Haemophilus paraphrophilus nov. sp. Journal of Pathology and Bacteriology 96, 413-419.

Zinnemann, K., Rogers, K. B., Frazer, J. \& DevaraJ, S. K. (1971). A haemolytic V-dependent $\mathrm{CO}_{2}$-preferring Haemophilus species (Haemophilus paraphrohaemolyticus, nov. spec.). Journal of Medical Microbiology 4, 139-143. 
